\title{
Egy- és többváltozós szürők a hitelrés alakulásának meghatározására
}

Tanulmányunkban a magyar hitelpiac ciklikus pozíciójának néhány lehetséges mérési módját hasonlítjuk össze. Három trendszürő-eljárással dekomponáljuk a magyar GDP-arányos hitelállomány idősorát trendre és ciklikus komponensre (hitelrésre): egyváltozós Hodrick-Prescott-szürővel, egyváltozós ChristianoFitzgerald-szürővel és többváltozós Hodrick-Prescott-szürővel. A dekompozíciót külön végezzük a háztartási és a vállalati szegmens esetében. A három módszer közül más változók információtartalmát is felhasználó többváltozós HodrickPrescott-szürő eredményei tükrözik leginkább a magyarországi hitelezési folyamatokkal kapcsolatos szakértői képet: a 2008-as válság kitöréséig - elsősorban a háztartási devizahitelezésnek köszönhetöen - a hitelrés folyamatosan nyílt. A válságot követő alkalmazkodás során a hitelrés zárult, sőt a nagymértékü csökkenés miatt negatív lett az értéke.*

Journal of Economic Literature (JEL) kód: C30, E32, G28.

\section{Szakirodalmi áttekintés}

A hitelpiacok ciklikus pozíciójának, a túlzott hitelezési időszakoknak a vizsgálata nem ismeretlen az irodalomban, és különösen a 2008-ban kezdődő válság hatására lett egyre népszerübb téma. A kérdés fontosságára Magyarországon a lakossági devizahitelezéssel kapcsolatos, társadalmi szinten is jelentős problémák világítottak rá. Számos, a későbbiekben bemutatott tanulmány alapján a túlzottan pozitív hitelrés (hitelciklus pozitív szakasza) makrogazdasági egyensúlytalanságok kialakulására utaló jel lehet, ami válságot okozhat. Ugyanakkor a túlságosan negatív hitelrés arra mutat rá, hogy a pénzügyi közvetítőrendszer nem tölti be

* A szerzők köszönettel tartoznak hasznos észrevételeikért Banai Ádámnak, Lieli Róbertnek, Várpalotai Viktornak és Világi Balázsnak.

Hosszú Zsuzsanna, Magyar Nemzeti Bank, Budapesti Corvinus Egyetem (e-mail: hosszuzs@mnb.hu). Körmendi Gyöngyi, Magyar Nemzeti Bank (e-mail: kormendigyo@mnb.hu).

Mérő Bence, Magyar Nemzeti Bank, Budapesti Corvinus Egyetem (e-mail: merob@mnb.hu).

A kézirat első változata 2015. augusztus 28-án érkezett szerkesztőségünkbe.

DOI: http://dx.doi.org/10.18414/KSZ.2016.3.233 
megfelelően a szerepét, és a gazdaság szereplöi számára nem képes elég pénzügyi forrást juttatni a gazdaságba.

A hitelrés alakulásának szabályozói szempontból is jelentős szerepe van. Magyarországon is - hasonlóan sok más országhoz - a makroprudenciális eszközrendszer egyik fontos eleme az anticiklikus tőkepuffer, amelynek meghatározása a hitelrésmutató alapján történik. Ezért is fontos egy olyan hitelrés kialakítása, amely időben stabil, megbízható eredményeket ad, és nem mutat nagy korrekciókat. A Bázeli Bankfelügyeleti Bizottság által kiadott útmutató ( $B C B S$ [2010]) szerint az anticiklikus tőkepuffer elsődleges célja, hogy a bankok tőkepuffert alakítsanak ki azokban az időszakokban, amelyekben nemzetgazdasági szinten túlzott hitelkiáramlás valósul meg, mivel ekkor jelentős rendszerszintü kockázatok épülhetnek fel. A tőkepuffer mértékének meghatározását támogatandó több tanulmány és nemzetközi ajánlás is született. A Bázeli Bankfelügyeleti Bizottság már említett útmutatója a GDP-arányos hitelállomány trendtől való eltérését (hitelrést) állítja a középpontba: részben a túlzott hitelnövekedés jelenségével való közvetlen kapcsolata miatt, részben pedig azért, mert széles nemzetközi mintát vizsgálva megfelelő indikátornak találta a rendszerszintű kockázatok kialakulásának elörejelzésére. ${ }^{1}$

Az anticiklikus tökepuffer bevezetésével kapcsolatban az Európai Rendszerkockázati Testület (European Systemic Risk Board, ESRB) is fogalmazott meg ajánlást (ERKT [2014], lásd még Detken és szerzőtársai [2014]). Ebben a Bázeli Bankfelügyeleti Bizottság által javasolt GDP-arányos hitelrés számítása mellett indokoltnak tartják alternatív számítási módszerek kidolgozását is, amennyiben az adott ország sajátosságai ezt indokolják.

Edge-Meisenzhal [2011] azt tesztelte, hogy milyen teljesítményt nyújtott volna a nemzetközi ajánlásban szereplő egyváltozós Hodrick-Prescott-szűrő, ha az anticiklikus tőkepufferre vonatkozó előírásokat korábban bevezették volna az Egyesült Államokban. Eredményeik alapján a módszer jelentős mérési hibákat követ el a valós idejü számításoknál, ami a téves jelzések miatt számottevő reálgazdasági költségekkel járt volna. Más egyváltozós trendszűrési módszerekkel is elvégezték a számításaikat, és ezekkel is hasonló következtetésre jutottak. A tanulmány eredményei azért is nagyon informatívak, mert a magyar idősorok az Egyesült Államok adataihoz képest sokkal rövidebbek, így a felmerült problémák itt fokozottabban jelentkezhetnek. Detken és szerzötársai [2014] nem a Hodrick-Prescott-szürőre épülö módszertan hibáinak javítására törekszik, hanem azt mutatja meg, hogy bár az így számított hitelrés az egyik legjobb válság-elörejelző indikátor, ennél is jobb eredményeket kaphatunk több indikátorra épülő rendszerek alkalmazásával. Ez a megállapítás viszont magára a hitelrésszámítás módszertanára vonatkozóan is lényeges: érdemes lehet megpróbálni a többváltozós szürési módszereket, hogy magába a hitelrés számításába is beépíthessünk minél több információt.

Többváltozós módszerek tekintetében a leggyakrabban használt eljárás a fellelhetö szakirodalomban a hibakorrekciós modellek (vector error correction model, VECM) becslése. A kelet-közép-európai hitelciklusokat Backé és szerzőtársai [2006] és Kiss és

\footnotetext{
${ }^{1}$ A részletes eredményeket Drehmann és szerzőtársai [2010] tartalmazza.
} 
szerzőtársai [2006] is vizsgálja hibakorrekciós modellel. Mivel ezek az országok felzárkózó periódusban vannak, és igen rövid idősorok állnak rendelkezésre, a kointegrációs egyenlet paramétereit az euróövezet országainak adatai alapján becslik meg, feltételezve, hogy ezek lennének érvényesek a vizsgálandó országokra is, amennyiben azok hitelállománya elérné a fejlettségüknek megfelelő szintet. A hosszú távú, egyensúlyi GDP-arányos hitelállományt a kointegráción keresztül az egy före jutó GDP-vel, a reálkamattal és az inflációval ragadják meg. Kiss és szerzőtársai [2006] az egyensúlyi hitelállomány becslését szektorális (vállalati és háztartási) szinten is elvégzi.

Endrész [2011] szintén magyar adatokon becsült hitelezést is figyelembe vevő VECM-et. Ennek során a vállalati hitelpiac és a nemzetgazdasági beruházások egymásra hatását vizsgálta hibakorrekciós modellkeretben. A tanulmány elsődleges célja nem a hitelrés becslése volt, hanem a hitelezés és a reálgazdaság kapcsolatának vizsgálata, de a hosszú távú kapcsolatot leíró egyenletekből ebben az esetben is származtatható egyensúlyi vállalati hitelpálya.

Végül az irodalom e részéből meg kell említenünk Buncic-Melecky [2014]-t, amelyben anticiklikus tőkepuffer számításához használták fel a paneladatokon elvégzett, VECMből kapott hitelrésbecslést. A tanulmány az egyensúlyi hitelállományt úgy számítja, hogy a kointegráció hosszú távú összefüggésének becslése után ciklusoktól megszűrt magyarázóváltozókat (GDP és GDP-deflátor) helyettesít a kapott összefüggésbe.

A VECM-ek mellett előforduló eljárás még, hogy a reálgazdaság és a hitelezés egyensúlyi kapcsolatának és egymásra hatásának megragadására állapottérmodelleket (elsősorban Kálmán-szürőt) használnak. Compton-da Costa e Silva [2005] a pénzügyi ciklust is figyelembe véve becsli meg az Egyesült Államok potenciális kibocsátását, illetve Mody és szerzötársai [2007] az észak-amerikai és fejlett európai országok egyensúlyi GDP-jét. Az állapottérmodellek a fent bemutatott modellekhez képest azzal az előnnyel rendelkeznek, hogy képesek strukturális, közgazdasági összefüggéseket is figyelembe venni a becslés során, méghozzá a VECM-ekhez képest általánosabb módon. Ugyanakkor minél több összefüggést szeretnénk szerepeltetni egy állapottérmodellben, általában annál nagyobb a becsült paraméterek száma, így a mintanagyság ebben az esetben is jelentős korlátozó tényező, amelyet paneladatok, illetve bayesi becslési eljárások alkalmazásával lehet ellensúlyozni.

Tanulmányunk további részében mi is áttekintjük a leggyakrabban alkalmazott egyváltozós szürők magyar idősorokon számított hitelréseit. Ezek eredményeiből már körvonalazódnak a magyar idősor sajátosságai és információtartalma. A HodrickPrescott-szűrőnek ismert többváltozós módosítása is, amely már képes bizonyos egyszerü közgazdasági összefüggések figyelembevételére is, így a hitelrés és a trend összefüggésbe hozható bizonyos reálgazdasági, illetve banki változókkal. Ezen eljárásnak létezik állapottér-reprezentációja is, tehát a becslés mögötti közgazdasági összefüggések megegyeznek egy egyszerü Kálmán-szürővel felírható modellével. A különbség a becslési eljárásban van: míg a többváltozós Hodrick-Prescott-szürő kis mintán is képes lehet megbecsülni viszonylag sok paramétert egy Kálmán-szüröhöz képest, utóbbi kevesebb feltevést igényel (a feltevések bemutatását a többváltozós szürővel foglalkozó fejezetben tesszük meg). Az itt bemutatott eredmények egy lehetséges továbbfejlesztésének tartjuk az állapottérmodellekre való áttérést. 


\section{A hitelállomány-adatok}

A vizsgálandó hitelállomány kijelölésekor egyrészt mindenképpen külön kívántuk választani a vállalati és a háztartási hitelállományt, másrészt törekedtünk a hitelnyújtó szerint lehető legszélesebb értelemben vett hitelállomány vizsgálatára, az adattartalom statisztikai következményeinek figyelembevétele mellett. A vállalati és háztartási hitelállomány szétválasztását fontosnak tartjuk, mert a két szektor hitelezési folyamatai erőteljesen eltérhetnek, és már az is súlyos következményekkel járhat, ha a kettő közül az egyik szektor hitelezése nem megfelelö. A két hitelállományt külön-külön vizsgálva, majd az eredményeket utólag összegezve kevesebb információ veszhet el, mintha csak egyben vizsgálnánk az állományokat. Modellezési szempontból is ez az egyszerübb megoldás, mivel eltérő gazdasági szerepük miatt más-más indikátorok segíthetnek azonosítani a két hitelállományban megfigyelhetö ciklusokat.

A hitelnyújtók szerinti lehetö legszélesebb kör meghatározását a pénzügyi számlák adatainak vizsgálatával, értelmezésével kezdtük (1. és 2. ábra).

\section{1. ábra}

A háztartási hitelállomány összetétele a hitelnyújtó szektor szerint

Milliárd forint

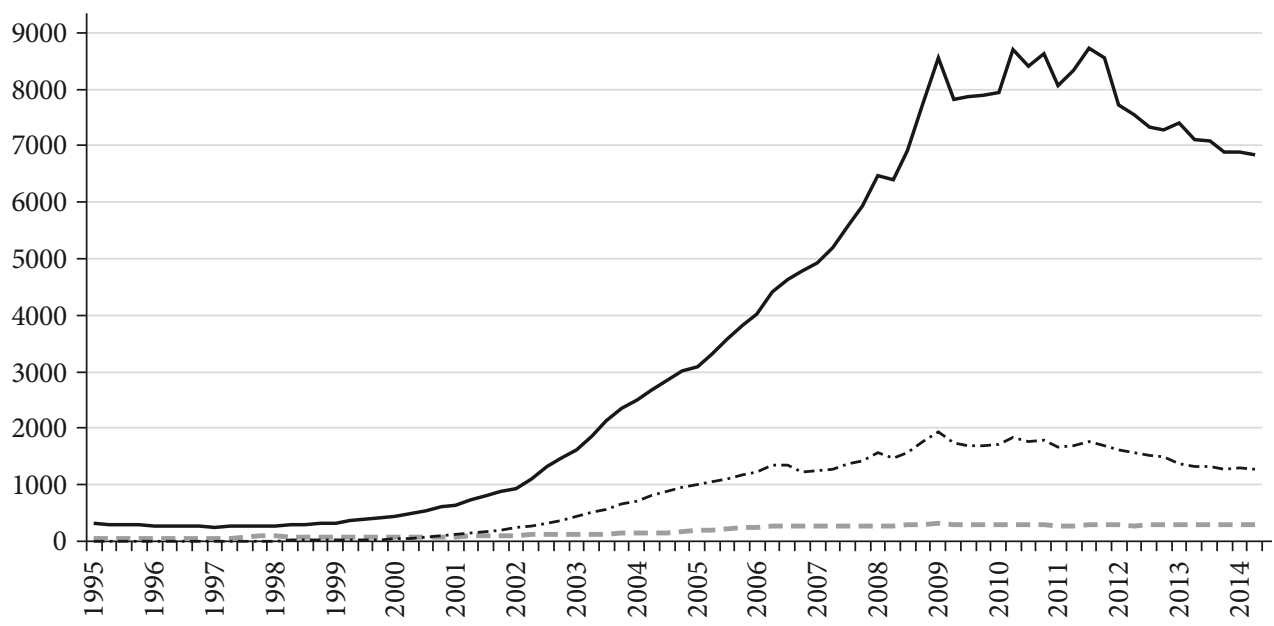

- Hitelek hitelintézetektől

-.-.- Hitelek egyéb pénzügyi vállalatoktól

- - - Hitelek nem pénzügyi vállalatoktól, az államháztartástól és külföldről

Forrás: MNB.

A háztartási hitelek túlnyomó részét a hitelintézetek és az egyéb pénzügyi vállalatok nyújtják Magyarországon, így az, hogy a nem pénzügyi vállalatok, az államháztartás és a külföld által nyújtott hiteleket bevegyük-e a vizsgálatba, csupán elvi jelentőségü, gyakorlati tétje nincsen. Hasonló okok miatt a nem pénzügyi vállalatok államháztartás és háztartások által nyújtott hiteleitől is eltekinthetünk, a külföld által nyújtott hitelekkel azonban más a helyzet. A külföldről felvett hitelek nagyrészt vállalatcsoporton belüli hitelek, ennek 
2. ábra

A vállalati hitelállomány összetétele a hitelnyújtás formája és a hitelnyújtó szektor szerint Milliárd forint

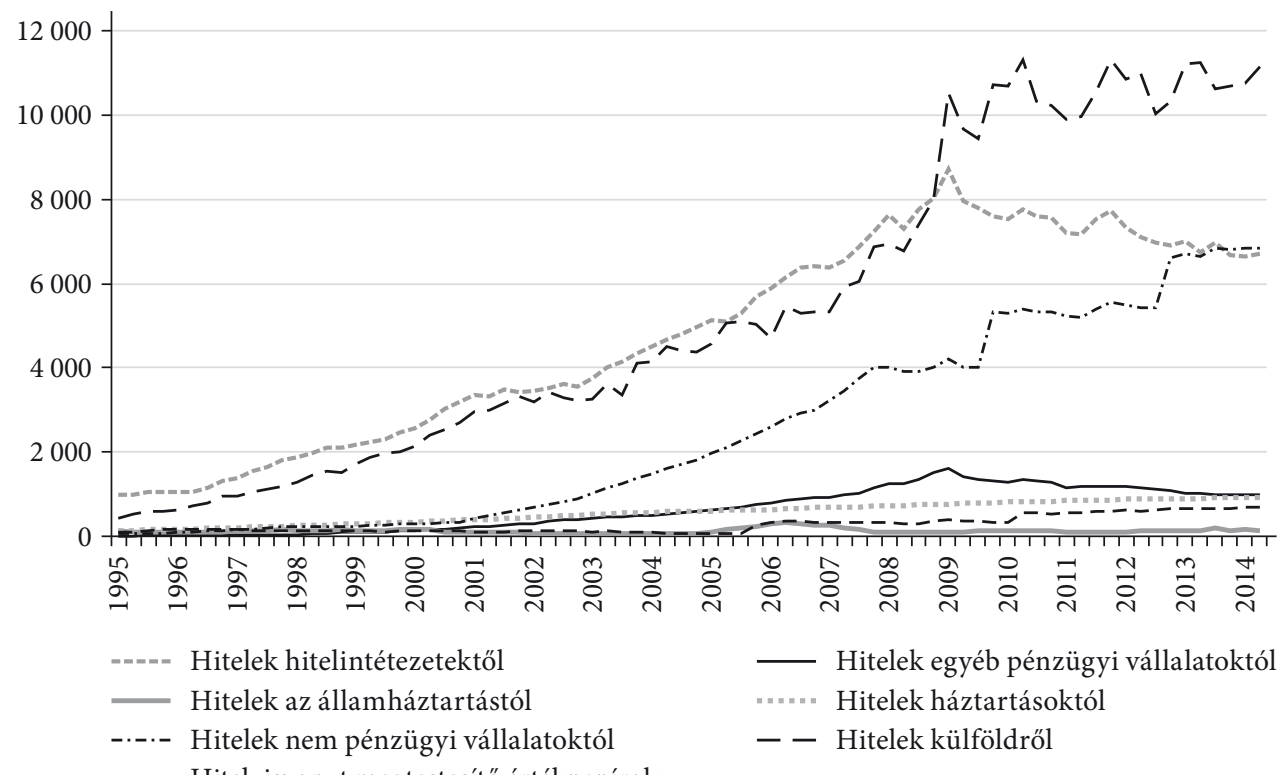

Forrás: MNB.

megfelelően előfordulhatnak olyan jelentős mértékủ állományváltozások, amelyek alig vagy egyáltalán nem befolyásolják a magyarországi nem pénzügyi vállalati szektor kockázatát. Ilyen tranzakciók lehetnek, amikor egy anyavállalat magyarországi leányvállalatán keresztül nyújt forrást egy másik országban müködő leányvállalatának, de az is jelentős állománymozgást idézhet elő, ha az anyavállalat változtat az általa nyújtott finanszírozáson belül a tőke és a hitel arányán. Mivel az említett esetekre nem tudunk adatsorainkban szürni, és a becslésekre ezek az események torzító hatással lehetnének, a nem pénzügyi vállalatok külföldi hitelei nem kerültek be a vizsgált hitelaggregátumba.

A nem pénzügyi vállalatok hiteleinek nem csekély része szektoron belüli hitel. Bár tudjuk, hogy a szállítói hitelek túlzott mértéke és a körbetartozások növekedése likviditási nehézségeket okozhat, ami emeli a szektor hitelkockázatát, mégis úgy döntöttünk, hogy számításaink során a szektoron belüli hiteleket nem vesszük figyelembe, mivel ezen állomány változása jelentős részben nem strukturális okokra vezethető vissza.

Bár a háztartások és a nem pénzügyi vállalatok hiteleinek vizsgálatát külön-külön végezzük el, biztosítani szeretnénk, hogy az eredmények összegezhetők legyenek. Emiatt a két szektor esetében azonos módon érdemes kijelölni a vizsgált hitelkört. A leírtaknak megfelelően végül a hitelintézetektől és az egyéb pénzügyi vállalatoktól felvett hiteleket vizsgáljuk a továbbiakban.

A magyar hitelállomány-adatok vizsgálatakor kulcsfontosságú kérdés a forintárfolyam kezelésének módja. Nemcsak azért, mert az állomány nagy hányada devizában denominált, hanem azért is, mert jelentős része még természetes módon sem fedezett, 
így az árfolyamkockázat közvetlenül megjelenik a hitelkockázatban. Maga a kockázat már a hitelek folyósításának pillanatától kezdve létezik, az árfolyam-elmozdulás „csupán” a kockázat realizációját jelenti, ezért olyan módszereket igyekeztünk keresni, amelyek lehetőleg az állomány felépülési periódusában képesek a kockázatokat jelezni, és nem magát az árfolyam-elmozdulás miatti automatikus átértékelést azonosítják túlzott hitelezésnek. Ezen okok miatt az árfolyamszürés mellett döntöttünk. Az árfolyamszüréshez a 2010. december 31-i árfolyamokat használtuk. Az árfolyamszürt hitelállomány tárgyidőszak végi értékét a szezonálisan igazított, elmúlt négy negyedéves nominális GDP arányában vizsgáltuk, így a mutatóban az infláció sem okoz problémát.

A vizsgálat időhorizontjával kapcsolatban a háztartási hitelek jelentik a szük keresztmetszetet. Bár már 1989 decemberétől rendelkezünk adatokkal, a háztartások hitelezése az ezredfordulóig csekély jelentőségű volt. A háztartási hitelállomány érdemi növekedése csak a kamattámogatásos lakáshitelek bevezetésével kezdődött el, ezért döntöttünk úgy, hogy vizsgálatunkat 2002 elejétől indítjuk. A leírtak alapján a vizsgált GDP-arányos hitelállomány alakulását a 3. ábra mutatja.

\section{3. ábra}

A hitelintézetektől és egyéb pénzügyi vállalatoktól felvett háztartási és vállalati hitelek árfolyamszürt állománya a GDP arányában (százalék)

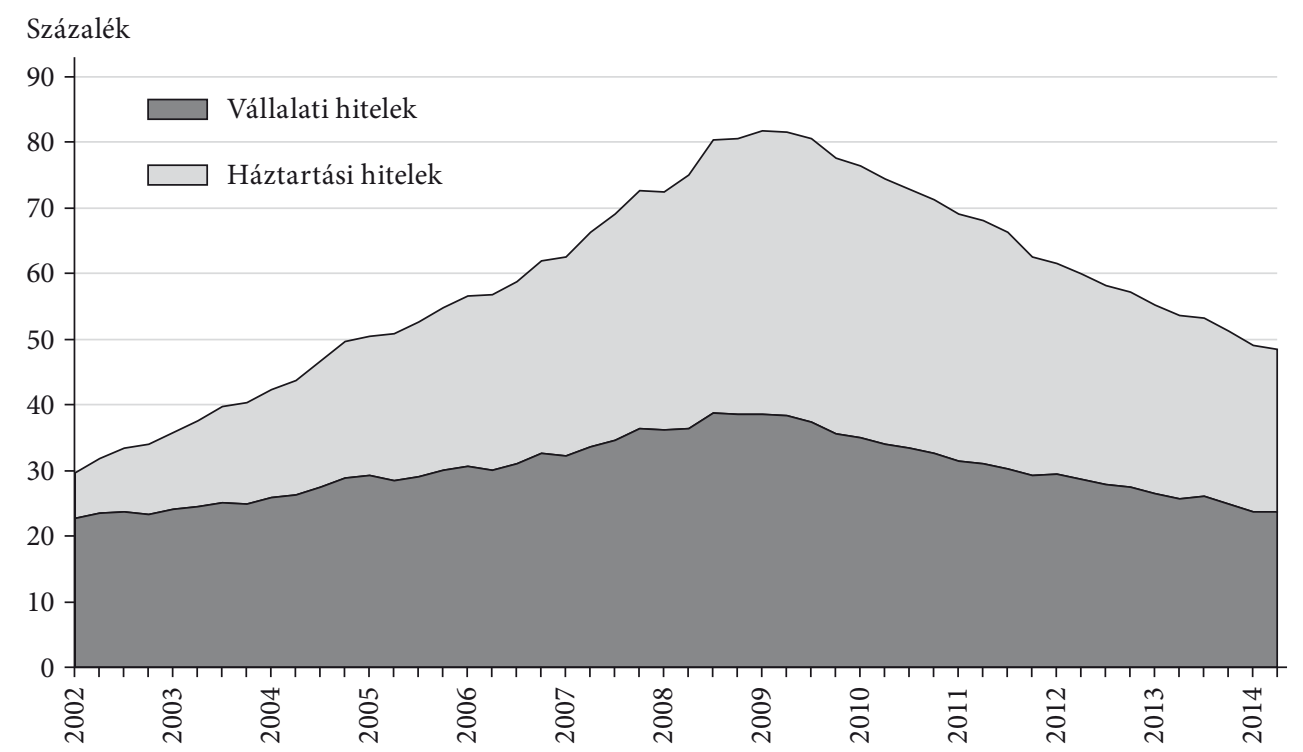

Forrás: MNB.

\section{Az egyváltozós szürök}

A következőkben a leggyakoribb egyváltozós trendszürési eljárásokat tekintjük át, illetve megvizsgáljuk, milyen eredményeket kapunk ezek alkalmazásakor a GDP-arányos hitelállományra. Áttekintjük azt is, milyen előnyös és hátrányos 
tulajdonságok szólnak e szűrők használata, illetve mellőzése mellett. Számos egyváltozós trendszürési eljárást ismerünk és használunk a közgazdasági idősorok vizsgálatára. Ezek nevüket onnan kapták, hogy a trend meghatározásához kizárólag a vizsgált idősorból indulnak ki, más információt vagy közgazdasági összefüggést nem használnak. E tulajdonság előnye és egyben hátránya is a módszercsaládnak: előnye, mert kicsi az adatigénye, hátránya, mert figyelmen kívül hagy számos információt, amelyek segítik a dekompozíciót, így gyakran téves eredményre juthatunk ezekkel a módszerekkel. Minden ilyen szűrési eljárásnál a trend-rés felbontás a kérdéses idősor valamilyen matematikai/statisztikai tulajdonságán alapul, a módszereket az különbözteti meg egymástól, hogy az idősort pontosan milyen jellemzője alapján vizsgáljuk. ${ }^{2}$ Ezek kiszámítása általában könynyen végrehajtható és nem igényel sok időt.

A felbontani kívánt változón kívül minden módszerhez szükséges némi külső információ: általában meg kell adnunk, hogy milyen hosszúságúnak gondoljuk az átlagos ciklus hosszát, ami a modellekben paraméterként jelenik meg. Ezeket a paramétereket többnyire empirikus adatok, szimulációk, illetve más trendszürési módszerek eredményei alapján határozzák meg. Bizonyos módszereknél és idősoroknál már kialakult a konszenzus az optimális paraméterezésről. Az egyes megközelítések azonban számos esetben nem állnak egymással összhangban, különböző országokra és idősorokra eltérő paraméterek lehetnek indokoltak, ezért a kevésbé vizsgált esetekben a paraméterezés jelentős becslési bizonytalanságot okozhat.

Egyváltozós módszerekkel az idősort fel lehet bontani egyoldali és kétoldali módon is. Egyoldali felbontás esetén a trend minden pontjának meghatározásához csak az adott időpontig rendelkezésre álló információt használjuk fel, míg kétoldali esetben a teljes minta alapján becsüljük meg a trendértékeket. Az egyoldali számítás előnye, hogy új adatok beérkezésével a korábbi időszakokban kapott trend-rés felbontás nem változik meg. Kétoldali esetben ezzel szemben minden új megfigyelés hatással lehet a trend múltbeli értékére is, viszont - mivel ebben az esetben bővebb információs halmazt használunk fel a becsléshez - általában pontosabb képet kaphatunk a trend és a rés alakulásáról. Az egyoldali módon számított trendek első néhány időszakát kénytelenek vagyunk kétoldali módon számítani, mivel nagyon kevés adatpontra nem lehet értelmes módon trendet illeszteni.

Végül meg kell jegyeznünk e módszerek egy nagyon fontos problémáját: általában nagy végponti bizonytalanság jellemzi az egyváltozós szürőket, ami miatt az új adatok beérkezésével a múltról alkotott képünk jelentősen megváltozhat. Ez a kétoldali felbontások esetén jelentős korrekciót igényel, ami bizonytalanná teszi a trendek és rések nagyságából levonható következtetéseket, illetve az ezeken alapuló gazdasági döntéseket. Az egyoldali felbontások technikailag ugyan nem értékelődnek újra, de a végponti bizonytalanság okozta probléma ebben az esetben is fennmarad, csak épp az egyoldali megközelítés elfedi. Erös végponti bizonytalanság esetén az egyoldali szürők a trend meghatározása helyett a bizonytalan végpontok idősorba füzését végzik.

\footnotetext{
${ }^{2}$ Erről részletesen a konkrét szűrők bemutatásánál fogunk írni.
} 


\section{Hodrick-Prescott-szürö}

Az egyváltozós módszerek közül a konkrét esetek bemutatását a közgazdasági idősorokra leggyakrabban alkalmazott szürővel, a Hodrick-Prescott-szürővel (a továbbiakban röviden HP-szürö) kezdjük (a módszerről részletesebben lásd Hodrick-Prescott [1997]). Ebben az esetben a trend az (1) minimalizálási feladat eredményeképpen adódik, ahol $r_{t}$ a vizsgált idősort, $\bar{r}_{t}$ a trendjét jelöli a $t$-edik időszakban:

$$
\min _{\bar{r}_{1}, \ldots, \overline{\bar{T}}_{T}} \sum_{t=1}^{T}\left(r_{t}-\bar{r}_{t}\right)^{2}+\lambda \sum_{t=2}^{T-1}\left[\left(\bar{r}_{t+1}-\bar{r}_{t}\right)-\left(\bar{r}_{t}-\bar{r}_{t-1}\right)\right]^{2} .
$$

Az első szumma azt a célt szolgálja, hogy a trend illeszkedjen a tényadatokra, míg a második értéke annál kisebb, minél „simább a trend”, azaz minél egyenletesebb a növekedési üteme. A két szempont relatív fontosságát fejezi ki a $\lambda$ paraméter. Ha csak az első szumma lenne a feladatban $(\lambda=0)$, a trend megegyezne a ténynyel, míg ha csak a második részt tekintenénk ( $\lambda$ közelít a végtelenhez), a trend teljesen lineáris lenne.

Minél hosszabb egy idősornál a feltételezett átlagos ciklushossz, annál nagyobb a $\lambda$ optimális értéke. Gazdasági ciklusok vizsgálatánál azt találták, hogy ezek átlagos hoszsza körülbelül 6-8 év. Negyedéves adatok esetében ennek körülbelül 1600-as $\lambda$ felel meg. Pénzügyi ciklusoknál ezzel szemben sokkal hosszabb ciklusokat tapasztaltak, az átlagos hossz ezek esetében körülbelül 30 év volt, ami 400 ezres $\lambda$-nak felel meg. A magyar pénzügyi ciklus esetén használható adatok 2002-től 2014 első feléig állnak rendelkezésre, azaz a mintánk hossza 12 és fél év, ami alatt még valószínűleg nem zárult le egy teljes pénzügyi ciklus, ezért nem egyértelmü, milyen $\lambda$-t érdemes választani.

A 4. ábrán kilenc különböző (hat és harminc év közötti) ciklushosszt feltételezve kiszámítottuk az egyoldali HP-szürt trendeket a hitel/GDP idősorokra. 2008 végéig kétoldali módon számítottuk a szűrőt, majd onnan tértünk át az egyoldali módszerre. Eredményeink alapján mind a vállalati, mind a háztartási szegmensben a 2010-es évig a HP-szürő egy szinte teljesen sima, lineáris trendet becsül, majd a hitelezés csökkenésével a becsült trendek egyre alacsonyabb értéket vesznek fel. Minél kisebb a $\lambda$ értéke, a szürt trend annál inkább követi a tényadatok alakulását, így annál gyorsabban húz vissza a tényadathoz: a hatéves ciklushosszt feltételezö trend a minta végére közel megegyezik a tényadattal, míg harmincéves ciklushossz esetén a hitelrés 15, illetve 7 százalék. Látható tehát, hogy a kapott eredményeket nagymértékben befolyásolja a $\lambda$ értékének megválasztása.

Ha egyoldali helyett a kétoldali módon számított HP-szürők eredményeit vizsgáljuk (5. ábra), látható, hogy hatéves ciklushosszal számolva a becsült trend szinte teljesen illeszkedik az adatokra, érdemi eltérést csak a 2008-2010-es időszakban tapasztalunk. Ezzel szemben a legnagyobb ciklushossznál a trend közel lineáris. Mivel trendbecslés esetén sem a tökéletes illeszkedés, sem a teljesen sima trend nem kívánatos, helyettük a két szempont optimális arányát szeretnénk látni, ezért a meglévő mintán a helyes ciklushossz valahol a két érték között, 15-20 év körül lehet.

Ahogy a 4. és az 5. ábrát összehasonlítjuk, látható, hogy az egyoldali és a kétoldali módon készített HP-trendek meglehetősen eltérő képet mutatnak. Ahogy említettük 


\section{4. ábra}

Egyoldali HP-trendek különböző ciklushosszokkal számolva

Százalék

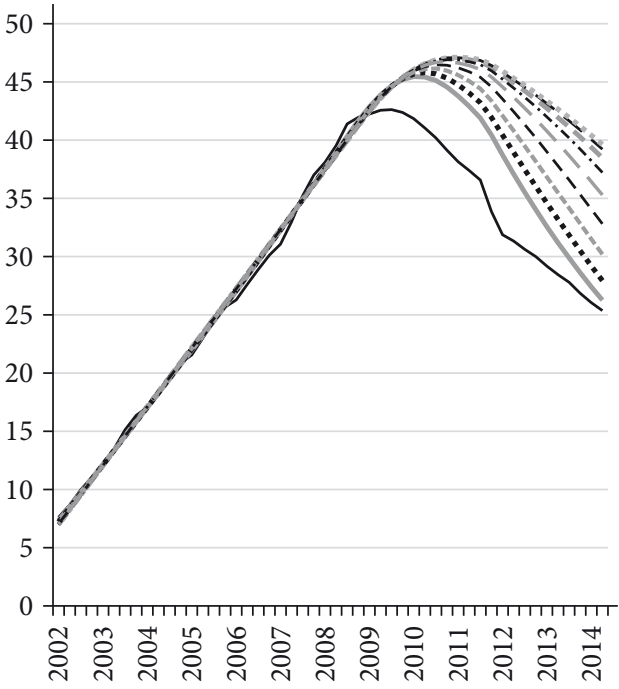

Százalék

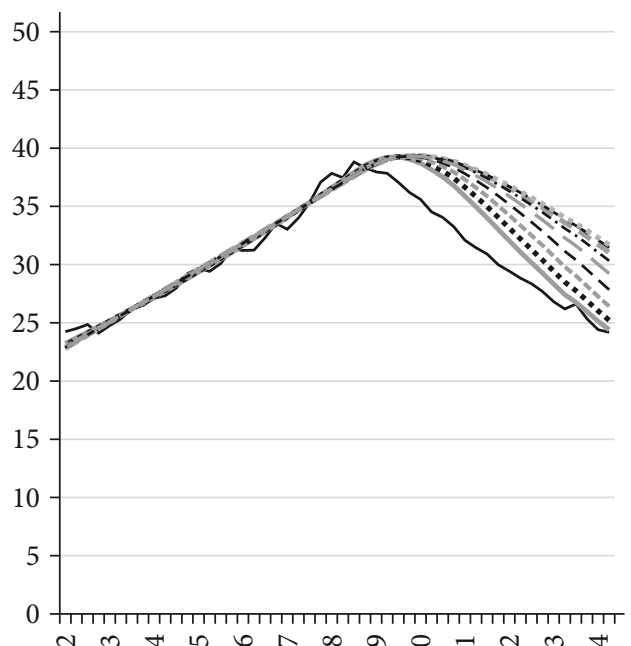

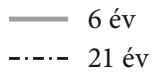

$=--=12$ év

-27 év
---15 év 30 év

Forrás: MNB.

\section{5. ábra}

Kétoldali HP-trendek különböző ciklushosszokkal számolva
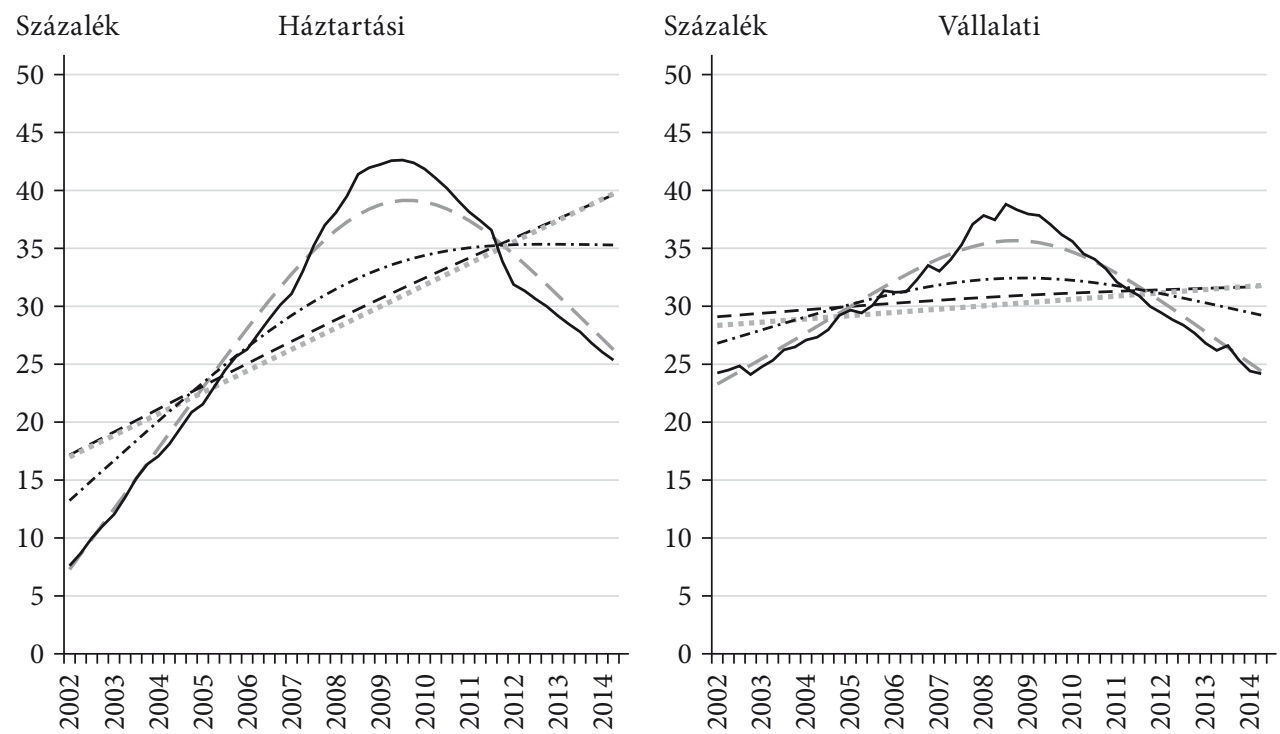

— Hitel/GDP - - 30 éves HP -.-. 18 éves HP $\quad-6$ éves HP "n.... Lineáris

Forrás: MNB. 
az egyváltozós módszerek általános bemutatásánál, ezeknél az eljárásoknál egy-egy új adat beérkezése jelentősen megváltoztathatja a múltról alkotott képünket is.

$\mathrm{Az}$ új adatok miatti korrekciók eredményét mutatja a 6. ábra. Ezen kétoldali módon számítottuk ki a trendeket, elöször csak a 2008 -as év végéig bejövő adatokat vettük figyelembe, majd mindig két negyedévvel bővítettük a megfigyelési időszakot. ${ }^{3}$ Ahogy látható, már két új adat beérkezése következtében is akár 3 százalékponttal megváltozhat az előző időszaki végpont, míg hosszabb távon akár több mint 10 százalékpontos különbséget is tapasztalhatunk az eltérő időszakokon számított trendértékek között.

6. ábra

Kétoldali HP-trendek különböző időintervallumokon becsülve
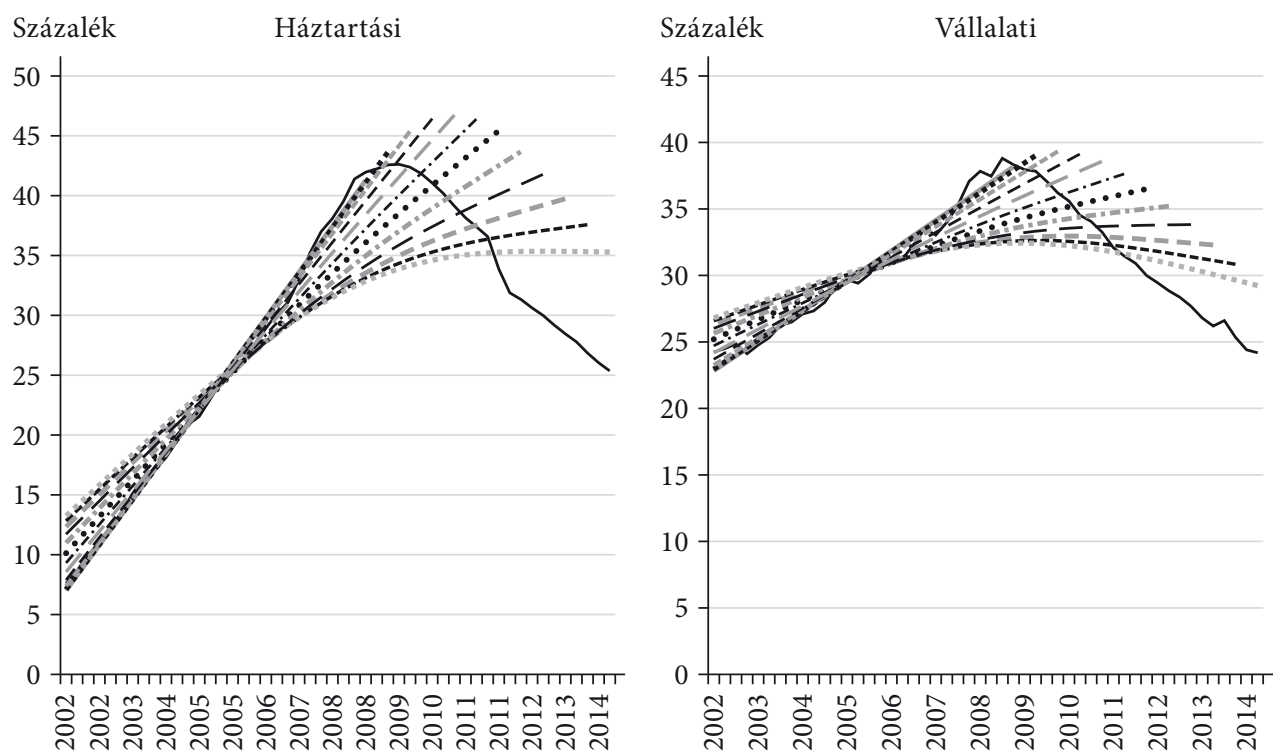

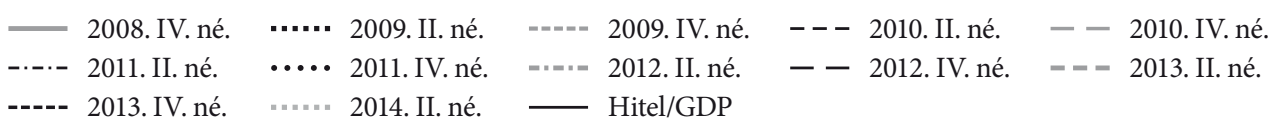

Megjegyzés: az ábra jelmagyarázata az egyes trendek számításánál ismert utolsó negyedévet mutatja.

Forrás: MNB.

Az ábrákon az is jól látható, hogy bár az egyoldali HP használatával nem történik korrekció a trendben, ugyanakkor a hitelciklus azonosításában nem nyújt segítséget. Sem a háztartási, sem a vállalati szegmensben semmilyen, túlzott hitelezésre utaló jelet nem lehet tapasztalni (korrekciók híján hosszabb időszakon sem), a trend szinte teljes mértékben együtt mozog a tényadattal. Ez egyben azt is jelenti, hogy a HP-szürö a teljes lakossági devizahitelezést egyensúlyi folyamatként azonosítja, amely erősen

\footnotetext{
${ }^{3}$ Mivel a túl kicsi és a túl nagy $\lambda$ értékeknél túlságosan szélsőséges megoldásokat ad a szűrő, ennél a számításnál közepes nagyságú, meglévő mintánknál kicsit hosszabb, 18 éves ciklushosszt feltételeztünk.
} 
megkérdőjelezi a módszer hitelességét. Ugyanakkor a válság kitörése óta - a legkisebb $\lambda$-jú trendet leszámítva - mindkét szektorban jelentősen kisebb a tényadat a becsült trendnél, azaz a hitelrés szignifikánsan negatív tartományban van. Így a jelenleg rendelkezésre álló adatok segítségével az egyváltozós HP-szürő semmilyen $\lambda$ paraméterérték mellett nem alkalmas pénzügyi ciklusok azonosítására.

\section{Christiano-Fitzgerald-szürö}

Tekintve, hogy a HP-szűrő nem nyújt megbízható teljesítményt a hitelciklus azonosításakor, érdemes más - de egyelőre továbbra is egyváltozós - szürési eljárást is tesztelni. A továbbiakban a Christiano-Fitzgerald-féle szürési eljárást mutatjuk be (a szürőről bővebben lásd Christiano-Fitzgerald [2003]), és megvizsgáljuk, milyen eredményre vezet a GDP-arányos hitelállomány-idősorainkon.

A Christiano-Fitzgerald-szürő (a továbbiakban röviden CF-szűrő) a frekvenciaszürők (band-pass) csoportjába tartozik. Az effajta szürési eljárások logikája a következő: az egyes idősorok különböző frekvenciájú részekből épülnek fel, és az adott ciklushosszal jellemezhető részek eltávolításával kapható meg a trend. Ezért ezeknél a szürőknél meg kell adni egy alsó és egy felső határt a ciklushosszra, amely alapján az idősor azon részeit, amelyek hossza a két érték közé esik, ciklusnak tekintjük, a felső határ fölötti részt trendnek, az alsó határ alattit pedig zajnak. Ezek az eljárások a trendet az eredeti idősor valamilyen kétoldali súlyozott mozgóátlagolásával állítják elö. A frekvenciaszűrők egymástól abban különböznek, hogy pontosan hogyan határozzák meg az átlagoláshoz a súlyokat.

Az eljárásoknak két csoportja van: a szimmetrikus és az aszimmetrikus eljárások. Szimmetrikus esetben egy adott pontban a trendérték kiszámításához ugyananynyi időszakot használ fel a szürő az időpont előttről, mint az időpont utánról, ezért a súlyok az időtől függetlenek. Ez azt eredményezi, hogy az idősor első és utolsó néhány megfigyelésére a szimmetrikus eljárások nem tudnak trendértéket mondani. Mivel számunkra a minta utolsó időszakai is fontosak, aszimmetrikus szürőre van szükségünk. Ebben az esetben az átlaghoz használt súlyok függenek attól, hogy melyik időpontra szeretnénk kiszámolni a trend értékét és az adatoktól is, azaz:

$\bar{r}_{t}=\sum_{c=1}^{T} w(t, c) r_{c} \quad t=1, \ldots, T$.

ahol $\bar{r}_{t}$ jelöli a trend értékét a $t$-edik időpontban, $r_{c}$ az idősor $c$-edik megfigyelése és $w$ az átlagoláshoz használt súly. Az aszimmetrikus frekvenciaszürők közül a CF-szürőt választottuk. Ahogy a HP esetében, itt is bemutatjuk a feltételezett ciklushosszra való érzékenységet és az új adatok beérkezésénél tapasztalható korrekció mértékét. A 7. ábra mutatja a feltételezett ciklushossz hatását. A HP-hoz hasonlóan először kiszámoltuk 2008 végéig kétoldali módon a trendeket, majd innen egyoldali eljárással hosszabbítottuk meg az idősorokat. Számításaink során az alsó ciklushossz értéinek mindig két negyedévet adtunk meg (vagyis nem bontjuk fel külön zajra és ciklusra a trenden kívüli részt), míg a felső értéket hat és harminc év között változtattuk. 
Ebben az esetben a HP-szüröhöz képest annyi a különbség az értelmezésben, hogy például a hat év a HP-trendnél azt a feltételezést jelentette, hogy hat év az átlagos ciklushossz, míg a CF-szürőnél a hat évnél nem hosszabb periodikus mozgásokat tekintjük a ciklus részének. A HP-szürővel összehasonlítva a CF-szürőt szembetünő különbség van az ábrák között: míg a HP-nál 2010-ig egyáltalán nem volt eltérés a különböző $\lambda$-jú trendek között, addig a CF-szürőnél már a minta kezdetétől fogva különböznek az eltérő paraméterezésű trendek. ${ }^{4}$

\section{7. ábra}

Egyoldali CF-trendek különböző ciklushosszokkal számolva
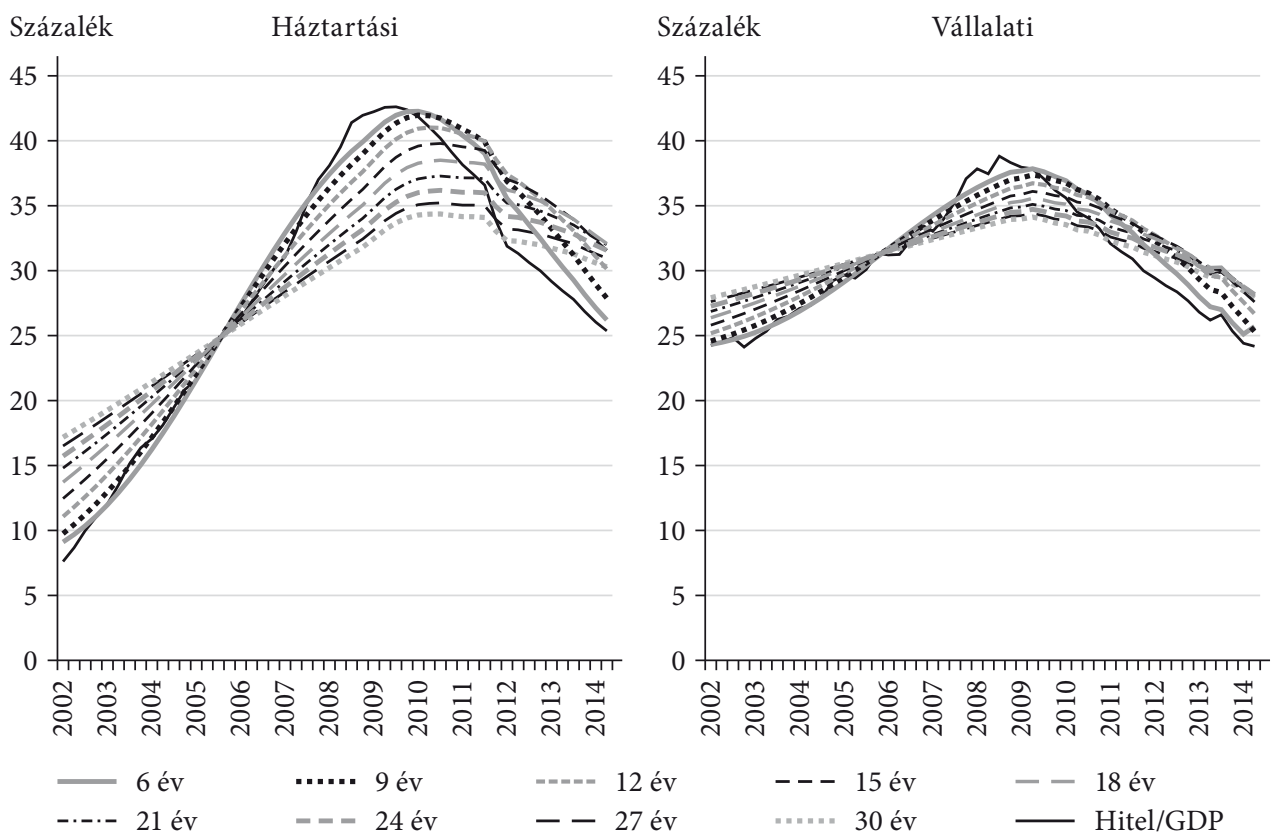

Forrás: MNB.

Az is látható a 7. ábrán, hogy 2006-ig a háztartási szegmensben a trend szinte minden paraméterérték mellett meghaladta a tényadatot (azaz a hitelrés negatív volt), majd 2006-tól 2010-2012-ig a tényadat vett fel magasabb értéket (pozitív hitelrés), végül azóta újra negatív hitelrés figyelhető meg. Továbbá, minél nagyobb a megengedett ciklusok felső határa, annál távolabb van egymástól a minta nagy részén a tény- és trendidősor. A háztartási szektor válság előtti túlzott hitelezésére utaló jelek ezért

\footnotetext{
${ }^{4}$ Meg kell említenünk, hogy a CF-szűrőre alkalmazott bizonyos feltételek érdemben befolyásolják ezeket az eredményeket. Egy CF-szürő becslésekor meg kell adnunk egy trendszürési feltételt, amire több lehetőségünk van. Az itt bemutatott eredményeknél azzal a feltételezéssel éltünk, hogy egy konstansból kiinduló véletlen bolyongás a trend. Ha ehelyett azt tesszük fel, hogy a trend eltolásos véletlen bolyongás, a HP-szürőhöz nagyon hasonló eredményeket kapunk (lásd a Függelék F1. ábráját). Ezt a feltevést azonban nem tartjuk helyesnek, mivel közgazdasági megfontolások alapján a fenntartható hitel/GDP csak bizonyos korlátok között vehet fel értéket.
} 
leginkább a 30 év hosszúságú ciklust is megengedő trendidősorban mutatkoznak meg. A vállalati szektorban a háztartásihoz hasonlóan alakult a trend és a tény egymáshoz való viszonya, csak a kettö közötti különbség kisebb, így ebben a szegmensben túlzott hitelezésre utaló jelet nem lehet látni.

Mivel a háztartási szektorban a hitelrés a harmincéves paraméterezésü trend mellett a legnagyobb, ezt a trendet vizsgáltuk meg korrekciók szempontjából (8. ábra).

\section{8. ábra}

Kétoldali CF-trendek különböző időintervallumokon becsülve
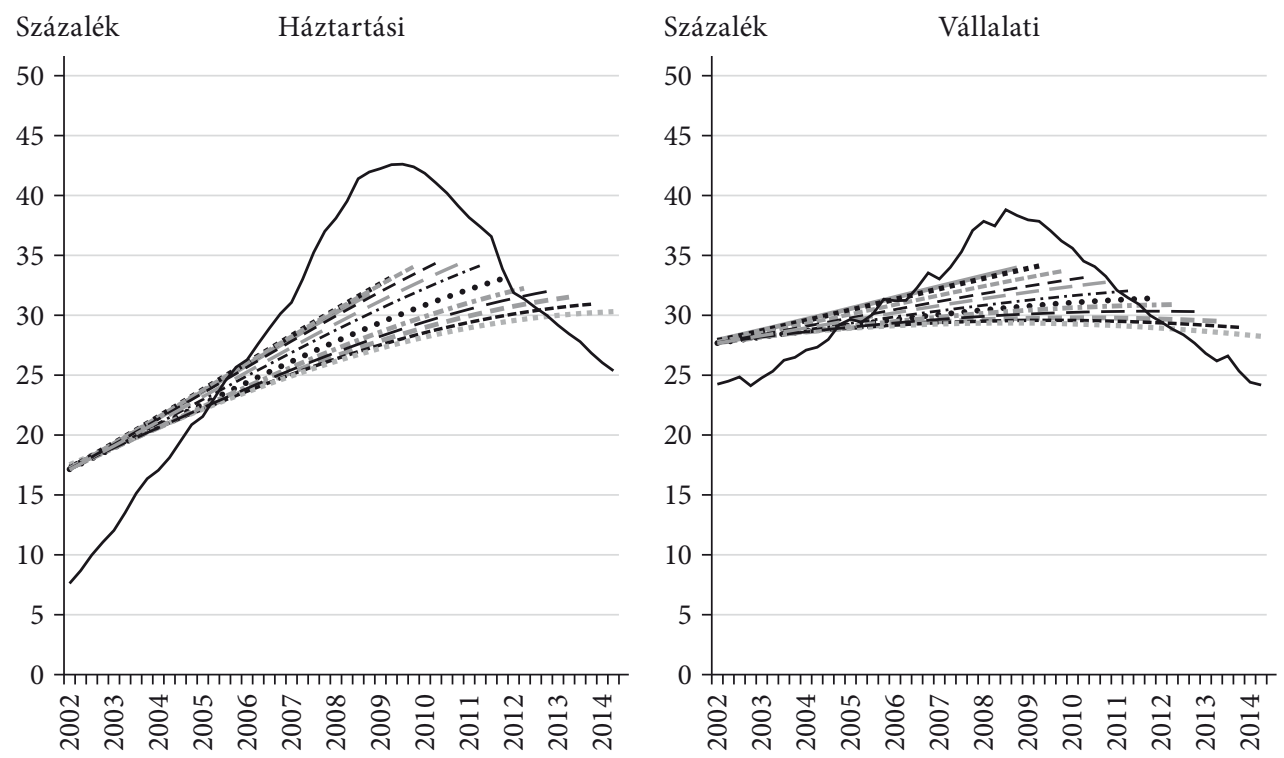

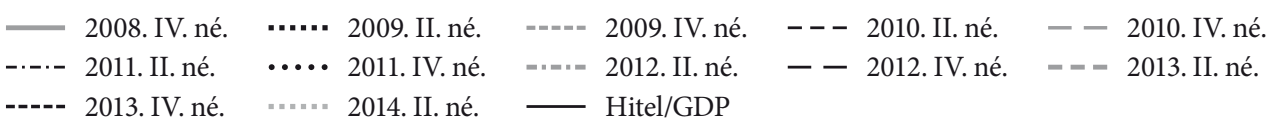

Forrás: MNB.

Ahogy a HP-szürőnél, itt is 2008 végéig futtattuk elöször a szürőt, majd mindig két negyedévvel növeltük meg a becslési mintát. Két új adat beérkezésével általában csak kismértékben változik a trend múltbeli értéke. Ez alól egy kivétel van a háztartási idősornál: a 2011. második félévi adatok beérkezése, ez a két negyedév azonban speciális volt, ekkor a végtörlesztés miatt hirtelen nagymértékben csökkent a háztartási hitelek állománya, ami a trend értékét visszamenőlegesen 1-2 százalékponttal csökkentette. Ezzel együtt is, mind a háztartási, mind a vállalati szegmensben az öt és fél évnyi új adat okozta korrekció sehol sem haladta meg a 6 százalékpontot, és összességében a korrekciók mértéke a HP-szürőhöz képest körülbelül feleakkora. Ez valószínüleg arra utaló jel, hogy a CF-szürö eljárása jobban képes kezelni azt az inkonzisztenciát, hogy a megfigyelési mintánk jelenleg valószínüleg rövidebb, mint egy hitelciklus hossza. A korrekciók mérete mellett ez az előny abban is megmutatkozik, hogy a CF-szürővel kapott trendek a rövidebb mintaperiódusokon is közelebb állnak a hitelezési ciklus trendjéröl alkotott elképzeléseinkhez. 


\section{Többváltozós Hodrick-Prescott-szürő}

A többváltozós módszerek lehetőséget adnak arra, hogy a célváltozó mellett más változókból nyert információkat is figyelembe vegyünk a rés meghatározásához. A szakirodalomban elsősorban a GDP-idősorok trendjének becslésére találunk többváltozós HP-szürő eljárásokat. Laxton-Tetlow [1992] a kanadai GDP trendjét próbálta meg számszerűsíteni az egyváltozós HP-szűrő továbbfejlesztésével: a HP-szűrő minimalizálandó kifejezését további két összefüggéssel egészítették ki, a Phillips-görbe egyenletével és az Okun-törvényt megragadó egyenlettel. A Phillips-görbe a kibocsátási rés és az infláció közötti kapcsolatot ragadja meg, az Okun-törvény pedig a kibocsátási rés és a munkanélküliség közötti összefüggést. Így a kibocsátási rés becsléséhez felhasználhatjuk kiegészítő információként az infláció és a munkanélküliség idősorát. Hirose-Kamada [2013] Japán esetében becsülték szimultán módon a potenciális kibocsátást és a Phillips-görbét többváltozós HP-szürő alkalmazásával, ahol potenciális kibocsátáson azt a kibocsátási szintet értették, amely esetében az infláció változatlan.

\section{A többváltozós Hodrick-Prescott-szürő módszertana ${ }^{5}$}

A többváltozós HP-szűrő esetében az egyváltozós változatot újabb összefüggésekkel bővítjük: közgazdasági megfontolások alapján a trend és egy vagy több változó között regressziós egyenleteket írunk fel, amelyeket szintén figyelembe veszünk az idősor szürése során. A trend és a bevont változó közötti logikai kapcsolat iránya tetszőleges lehet: a regressziós kapcsolatot akkor is felírhatjuk, ha a trend alakulása befolyásolja a bevont változóét, hiszen ebben az esetben is lehet következtetni a bevont változó értékéből a trend értékére.

Az egyváltozós esethez hasonlóan - amikor a trend megfigyeléstől való eltérését hibatagként szerepeltetjük a minimalizálandó kifejezésben - a többváltozós szűrő felírásakor a trend és a magyarázóváltozók közötti regressziós kapcsolat hibatagját vesszük figyelembe. Mivel azt gondoljuk, hogy a regresszióval leírt kapcsolatnak fenn kell állnia, büntetjük az attól való eltérést. Amennyiben több kapcsolat meglétét is feltételezzük egyszerre, több regressziós egyenlet hibatagját is szerepeltetnünk kell. A regressziós kapcsolat együtthatóit nem kell elöre ismernünk, azokat a trend szürésével együtt becsülhetjük.

A GDP-arányos hitelállomány trendjének meghatározásakor két regressziós egyenletet veszünk figyelembe: egyes változók a ciklikus komponenst (hitelrést) magyarázhatják, vagyis a megfigyelt adat trendtől való eltérését, míg más változók közvetlenül a trend nagyságát. Ennek megfelelően az alkalmazott többváltozós HP-szüröt a következő formulával adhatjuk meg:

\footnotetext{
${ }^{5}$ Az általunk használt módszertan és a szakirodalomban fellelhető többváltozós HP-szűrők közötti különbségeket a Függelékben ismertetjük.
} 
$\min _{\left\{\bar{r}_{t}\right\}_{t=1}^{T},\left\{\beta_{i}\right\}_{\mathrm{i}=1}^{N},\left\{\gamma_{i}\right\}_{\mathrm{i}=1}^{M}, c_{C}, c_{T}}\left\{\lambda_{c} \sum_{t=1}^{T}\left(r_{t}-\bar{r}_{t}\right)^{2}+\lambda_{H P} \sum_{t=2}^{T-1}\left(\Delta \overline{r_{t+1}}-\Delta \bar{r}_{t}\right)^{2}+\lambda_{\varepsilon} \sum_{t=1}^{T} \varepsilon_{t}^{2}+\lambda_{v} \sum_{t=1}^{T} \nu_{t}^{2}\right\}$,

$r_{t}-\bar{r}_{t}=c_{C}+\sum_{i=1}^{N} \beta_{i} x_{i t}+\varepsilon_{t}$

$\bar{r}_{t}=c_{T}+\sum_{i=1}^{M} \gamma_{i} y_{i t}+\nu_{t}$

ahol a (3) a szürés során minimalizálandó kifejezés, a (4) a ciklikus komponensre, az (5) pedig a trendre felírható regressziós egyenlet; $r_{t}$ a GDP-arányos hitelállomány mutató értéke, $\bar{r}_{t}$ pedig a GDP-arányos hitelállomány trendjéé, $x_{i t}$ a ciklikus komponenst magyarázó változók, $\beta_{i}$ pedig ezek együtthatói, $y_{i t}$ a a trendet magyarázó változók, $\gamma_{i}$ pedig ezek együtthatói, $c_{C}$ és $c_{T}$ a becsült egyenletek konstansai.

A minimalizálandó kifejezés az egyváltozós HP-szűrő két komponense mellett még két tagot tartalmaz: a ciklikus komponensre és a trendre felírt regressziós kapcsolat hibatagjait. Mivel a ciklikus komponens és a trend egyenletében nem ismerjük a magyarázóváltozók együtthatóit, ezeket is meg kell becsülnünk, mégpedig a trend értékével együtt. Így a (3) kifejezést nemcsak az egyes időszakokra vonatkozó trendértékek alapján minimalizáljuk, hanem a magyarázóváltozók együtthatói alapján is. A minimalizálás során a (3) kifejezésben szereplő $\varepsilon_{t}$-t és $v_{t}$-t helyettesíteni kell a (4)-ből és (5)-ből származó kifejezésekkel.

A becslés során meg kell adnunk az egyenletekben szereplő magyarázóváltozókat, illetve az egyes tagokhoz tartozó, a minimalizálás során alkalmazott súlyok $\lambda$ értékét. Ezek meghatározása ugyanakkor nem magától értetődő: optimális értékük függhet például az egyes idősorok szórásától, a ciklus hosszára vonatkozó elképzelésektől vagy az egyes idősorok kölcsönhatásától a regressziós egyenletekben. A magyarázóváltozók meghatározása sem egyértelmü, hiszen a különböző kombinációik más és más eredményre vezetnek. A problémák kezelése érdekében amellett döntöttünk, hogy sokfajta módon - a potenciális magyarázóváltozók és a $\lambda$-k megfelelő kombinációi mellett - futtatjuk le a többváltozós HP-szűrőt, majd átlagoljuk azokat, amelyek az alábbi elvárásainknak eleget tesznek.

1. 2008 második negyedévére a trend értéke a tényadat 60 és 95 százaléka között legyen, hiszen szakértői képünk alapján a válság kitörésekor már túlfutás volt a hitelezésben.

2. A szüréshez felhasznált regressziós egyenletekben a bevont magyarázóváltozók együtthatójának előjele közgazdaságilag indokolt legyen.

3. A bevont magyarázóváltozók hatása legyen közgazdaságilag szignifikáns. A becslés sajátosságai miatt a magyarázóváltozók standard hibái alapján nem következtethetünk a szignifikanciára, ezért azt a változót tekintettük szignifikánsnak, amelyik a vizsgált időhorizonton legalább 2 százalékpontos hatással van a trend értékére. Ez azt jelenti, hogy az adott magyarázóváltozó legnagyobb és legkisebb értékét behelyettesítve a megfelelő egyenletbe, a GDP-arányos hitelállomány trendjére vonatkozó hatások között legalább két százalékpontnyi különbségnek kell lennie. 
4. Az alkalmazott becslés legyen robusztus: ha változtatunk (rövidítünk) a becsléshez felhasznált időhorizont hosszán (maximum két évet), a rövidebb idősor utolsó időszakára kapott trend értéke maximum 2 százalékponttal térjen csak el a teljes időhorizont alapján becsült trend adott időszakra vonatkozó értékétől, illetve a rövidebb idősoron becsült trendidősorra is teljesüljenek az 1-3. feltételek.

A GDP-arányos háztartási hitelállomány idősorának szűrése során a ciklikus komponens egyenletéhez a következő változókat használtuk:

- globális hitelrés ${ }^{6}$ - a becsült együtthatónak pozitívnak kell lennie, mert a globális folyamatok begyürüzhetnek egy kis nyitott gazdaságba;

- reál-GDP ciklikus komponense (magyar kibocsátási rés) ${ }^{7}$ - a becsült együtthatónak pozitívnak kell lennie, mivel a gazdasági túlfütöttség általában növeli a kockázatvállalási kedvet;

- a lakáshitelek és a fogyasztási hitelek súlyozott állományi kamatlába - a becsült együtthatónak negatívnak kell lennie, mert a kamatok emelkedése nehezíti a hitelfelvételt és csökkenti a keresett hitelmennyiséget;

- Bubor - az együtthatójának szintén negatívnak kell lennie, hiszen a Bubor növekedése általában a hitelkamatok növelésével társul;

- bankrendszeri tőkeáttétel (a teljes bankrendszer eszközállományának saját tőkéhez viszonyított aránya) - a becsült együtthatónak pozitívnak kell lennie, mert a tökeáttétel növekedése hitelezési felfutást jelezhet;

- hitel/betét mutató a bankrendszer egészére - a becsült együtthatónak pozitívnak kell lennie, mert a hitel/betét mutató növekedése hitelezési felfutást jelezhet;

- marketingköltségek (bankrendszeri szinten, reálértéken, a szezonális hatások szürése érdekében mozgóátlagolással) - a becsült együtthatónak pozitívnak kell lennie, mert a lakossági hitelkínálat bővülését általában jelentős marketingkampányokkal igyekeznek a bankok az ügyfelek tudomására hozni.

A vállalati hitel/GDP idősorának szürése során a ciklikus komponens egyenletében szintén szerepeltettük a háztartási hitel/GDP idősora esetében is használt globális hitelrés, kibocsátási rés, Bubor, tőkeáttétel és hitel/betét mutatókat, ezek mellett pedig az új kihelyezésủ vállalati hitelek kamatlábát vizsgáltuk, valamint a GKI üzleti bizalmi indexet. A kamatláb esetében negatív, az üzleti bizalmi indexnél pedig pozitív együtthatót írtunk elö.

A háztartási és a vállalati trendegyenletben a reál-GDP logaritmusát szerepeltettük, az együtthatónak pedig pozitívnak kellett lennie, mert empirikus adatok alapján

\footnotetext{
${ }^{6}$ A globális hitelrés kiszámításához 12 OECD-tagállam (Ausztrália, Belgium, Dél-Korea, Egyesült Államok, Egyesült Királyság, Finnország, Franciaország, Japán, Németország, Norvégia, Spanyolország és Svájc) GDP-arányos hitelállományait súlyoztuk össze vásárlóerő-paritáson 1980 és 2014 között, az így kapott idősorból pedig egyváltozós Hodrick-Prescott-szűrő segítségével határoztuk meg a hitelrést egyoldali módon (vö. Alessi-Detken [2011]).

${ }^{7}$ A GDP-idősor szintén felosztható trendre és kibocsátási résre: a kibocsátási rés feltételezhetően inkább csak rövid távon növeli a hitelezést, illetve a hitelfelvételt, a hitelezés hosszú távú egyensúlyi szintjét pedig valószínüleg inkább a potenciális GDP határozza meg.
} 
a magasabb GDP arányaiban is növekvő hitelfelvételt indokolhat hosszú távon (vö. Kiss és szerzötársai [2006]). A logaritmikus transzformálásra két okból volt szükség: egyrészt a GDP növekedésének hatása a GDP-arányos hitelállományra egyre kisebb lehet, másrészt a kapott együttható értelmezése is kézenfekvőbb: azt mutatja meg, hogy egyszázalékos GDP-növekedés hány százalékponttal növeli a GDP-arányos hitelállomány hosszú távú értékét. A trendegyenletben a reál-GDP logaritmusa mellett ugyanezen idősor Kálmán-szürővel nyert trendjét is vizsgáltuk. Emellett a háztartási trendegyenletben pozitív előjellel a reál-munkajövedelem logaritmusát is szerepeltettük, hiszen a magasabb munkajövedelmek nagyobb mértékủ hitelfelvételt tesznek lehetővé a háztartások számára. ${ }^{8}$

A felsorolt változók mellett mind a háztartási, mind a vállalati becslés során vettük az összes olyan lehetséges kombinációt, amikor a ciklikus komponens egyenletében egy, kettő vagy három változó szerepelt, a trend egyenletében azonban egyszerre csak egy változót használtunk. Vizsgáltuk azokat a lehetőségeket is, amikor nem szerepeltettük a ciklikus komponens vagy a trend regresszióját.

A szürő képletében négy $\lambda$ szerepel, ezeknek azonban csak az egymáshoz viszonyított nagysága számít, ezért az egyiket szabadon megválaszthatjuk. Ennek megfelelően $\lambda_{H P}$, vagyis a trend növekedésének egyenletességét tartalmazó komponens értékét 1-nek vettük. Mivel a harmadik komponens a tényadattól való eltérést magyarázza, ezért ha a becslésben szerepel a ciklikus komponens regressziója, felesleges pozitív súllyal büntetni a tényadattól való abszolút eltérést, vagyis az első komponenst. Az első és a harmadik komponens közül tehát a továbbiakban egyszerre mindig csak az egyikkel számolunk: ha szerepel a becslésben a ciklikus komponens regressziója, akkor $\lambda_{\varepsilon}$ pozitív, és $\lambda_{c}$ értéke 0 , ellenkező esetben pedig fordítva. A továbbiakban az első és a harmadik komponens közül a (3) kifejezés ciklikus komponensének azt fogjuk hívni, amelyiket pozitív súllyal szerepeltetjük. Összességében tehát legfeljebb csak két $\lambda$-t kell meghatároznunk: a ciklikus komponensét és a trendegyenlethez tartozót (amikor van trendegyenlet). Az egyszerüség kedvéért csak a $\lambda$-k nagyságrendjén változtattunk, mindkét esetben a következő $\lambda$-értékeket vizsgáltuk: 0,0001, 0,001, 0,01, 0,1, 1, 10, 100 és 1000.

Mivel a ciklikus komponens regressziójában és a trendegyenletben is szerepel konstans, a kapott trend tetszöleges eltolása esetén is ugyanakkora lenne a célfüggvény értéke, vagyis a minimalizálási feladat nem lenne jól determinált. Ennek kiküszöbölésére valamelyik időpontra rögzítenünk kell a trend értékét, hogy ezáltal egyértelmű legyen a megoldás. A háztartási és a vállalati idősor esetében is az első időszak trendjének értékét rögzítettük: mivel megfelelt szakértői képünknek, a teljes mintán egyváltozós HP-filterrel becsült trend értékét vettük, vagyis a háztartási hitel/GDP trendjének becslésekor az első időszaki trend értékét 13,2, a vállalati idősornál pedig 26,8 százalékon rögzítettük.

\footnotetext{
${ }^{8}$ Itt csak azon változókat soroljuk fel, amelyek szerepeltek valamelyik, a feltételeknek eleget tevő trendidősor becslésében. Az e cikk elözményének tekinthető Hosszú és szerzötársai [2015]-ben az öszszes vizsgált változót felsoroljuk a várt együtthatójukkal együtt.
} 


\section{Az eredmények bemutatása}

A 9. ábrán láthatjuk, hogy az alkalmazott módszertan milyen trendet becsül a GDP-arányos háztartási, illetve vállalati hitelállomány-mutatóra a 2002 első negyedéve és 2014 második negyedéve közötti időszakon. A megadott feltételeknek sok idősor megfelel, az idősorok átlaga és mediánja mellett feltüntettük azt is, hogy az adott időszakra milyen intervallumba került a becsült trendértékek 50, 75, illetve 90 százaléka. A középső 90 százalék eredményei alapján az intervallum terjedelme a háztartási idősor esetében az utolsó időszakra körülbelül 14 százalékpont, a vállalati idősor esetében pedig nagyjából 8 százalékpont. Amennyiben a kapott idősorok átlagaként értelmezzük a többváltozós módszertan segítségével számított trendet, a háztartási idősor esetében a kezdeti növekedés után a háztartási trend nagyjából 31 százalékon tetőzik, majd némileg csökken, a vállalati trend pedig enyhe növekedést követően 30 százalék körüli szinten stagnál.

9. ábra

A többváltozós HP-szűrő által becsült trendek eloszlása

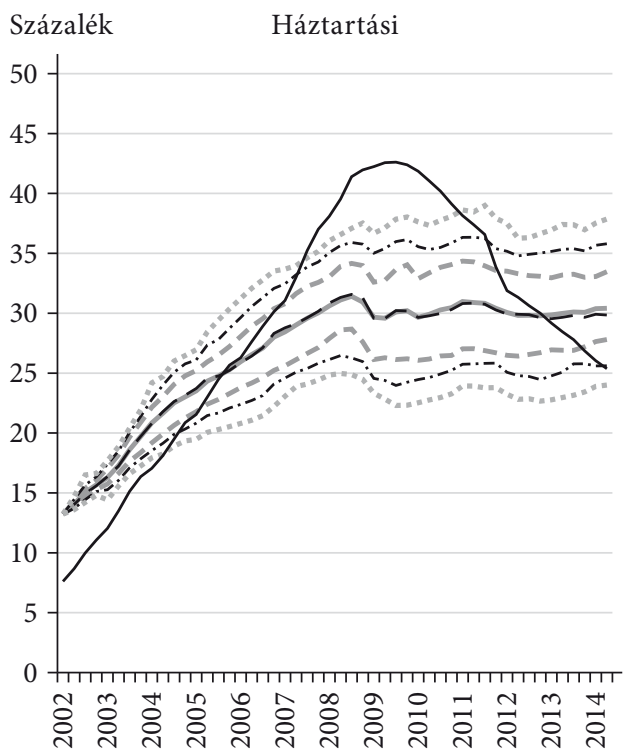

- Hitel/GDP

- - Többváltozós HP-trendek mediánja

-.-.- Többváltozós HP-trendek - 75 százalék

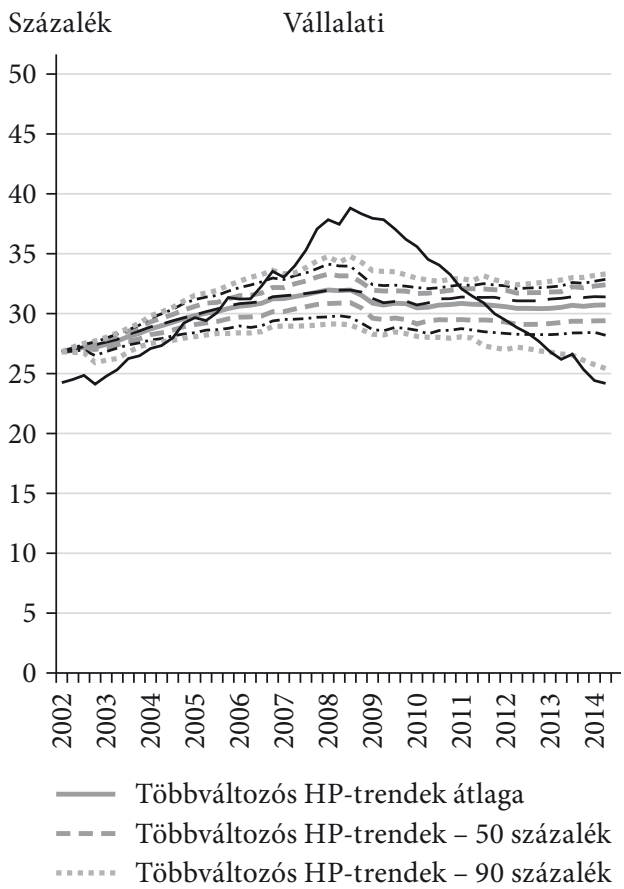

Forrás: MNB.

Az eredményt kismértékben változtatná meg, ha a becslésbe bevont változókkal kapcsolatban minimum két százalékpontos hatás helyett más szignifikanciakritériumot alkalmaznánk: egy vagy három százalékpontos kritérium esetén a háztartási szegmensben a változás mértéke elhanyagolható, míg a vállalati szegmensben ez körülbelül fél-egy százalékponttal módosítja az egyes negyedévekre kapott eredményeket (lásd Függelék F2. ábra). Ez azt jelenti, hogy a háztartási szegmens 
esetében a bevont változók hatása kellően nagy, míg a vállalati szegmensben az elvárt hatás növelésével több változó kimarad a becslésből.

Ha a megadott kezdőértéket növeljük vagy csökkentjük 2 százalékponttal, akkor a háztartási szegmensben a kapott trendértékek a felépülési szakasz alatt konvergálnak, a vállalati szegmens esetében azonban inkább eltolódnak (lásd Függelék F3. ábra).

Érdemes megvizsgálni, mennyire robusztus az alkalmazott többváltozós szürő, ha az átlagokat nézzük. A 10. ábrán láthatjuk, hogyan alakul a becsült trend értéke, ahogyan növeljük a szüréshez - és ezzel párhuzamosan a becsléshez - felhasznált idősor hosszát 2008 negyedik negyedévétől egészen 2014 második negyedévéig. Összevetve korábbi ábráinkkal, láthatjuk, hogy a többváltozós HP-szürő a többi szürőhöz képest robusztusabb eredményeket produkál.

10. ábra

Többváltozós HP-trendek különböző időintervallumokon becsülve
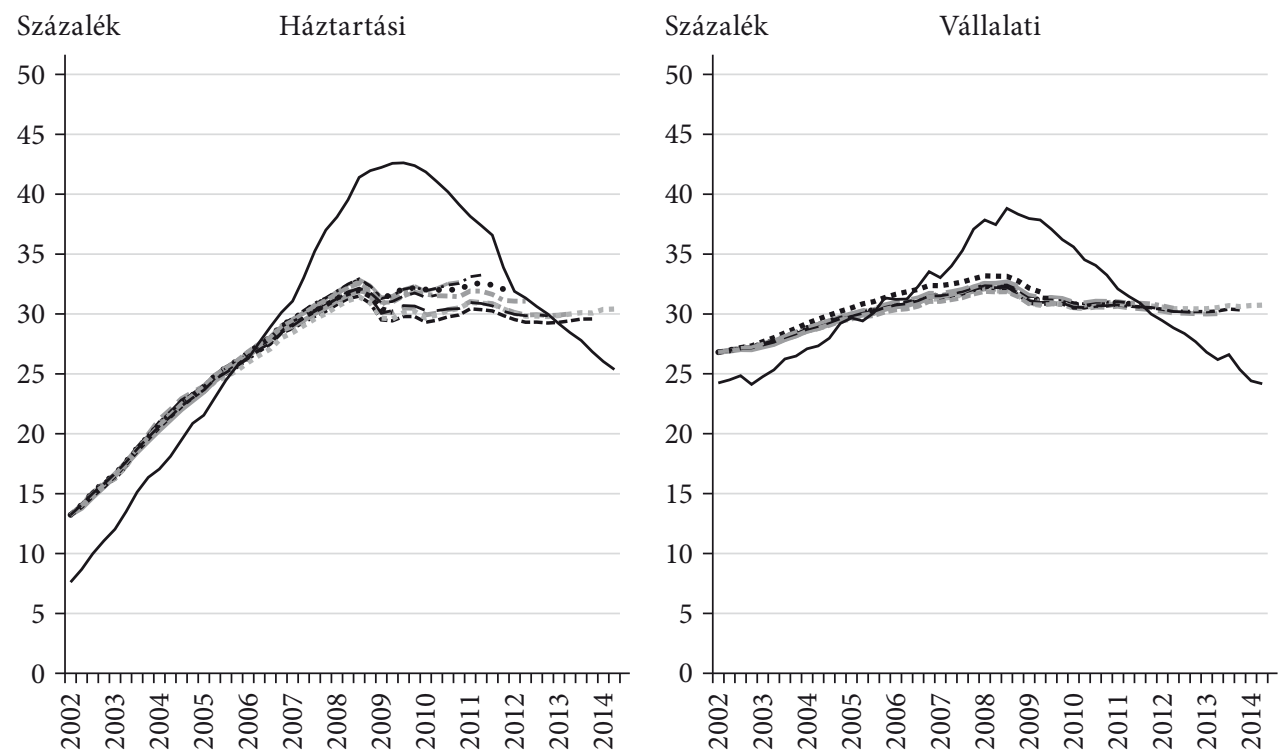

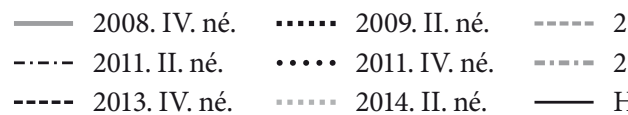

2009. IV. né. - - - 2010. II. né. $\quad$ - 2010. IV. né. 012. II. né. $\quad-\quad$ 2012. IV. né. $\quad-=-$ 2013. II. né.

Forrás: MNB.

A kapott trendet összevethetjük az egyváltozós módszerek által becsült eredményekkel (11. és 12. ábra), mégpedig az egyváltozós HP-szürővel, valamint a hitel/GDP idősor szürésére legjobbnak tűnő egyváltozós módszer, a ChristianoFitzgerald-szürő eredményével. Az összevetéskor az egyoldali módon számított

\footnotetext{
${ }^{9}$ Mivel a többváltozós HP-szűrő regressziós egyenleteinek becsléséhez kell egy kiindulási mintaidőszak, a szűrőket 2008 végéig kétoldali módon becsültük, majd onnantól kezdve egyoldali módon hosszabbítottuk meg.
} 
értékekből indulunk ki, hogy lássuk, mekkora hitelrést jeleztek volna az egyes mutatók a különböző időpontokban. Az ábrák alapján látható, hogy az egyváltozós HP-szürő nem jelez túlfutást, sőt az állomány leépülése miatt a válságot követően igen nagy negatív hitelrést mutat. A CF-szürő és a többváltozós HP-szürő azonban jelzi a pozitív hitelrés felépülését.

\section{1. ábra}

Egyváltozós szűrők és a többváltozós HP-szűrő összehasonlítása - trend
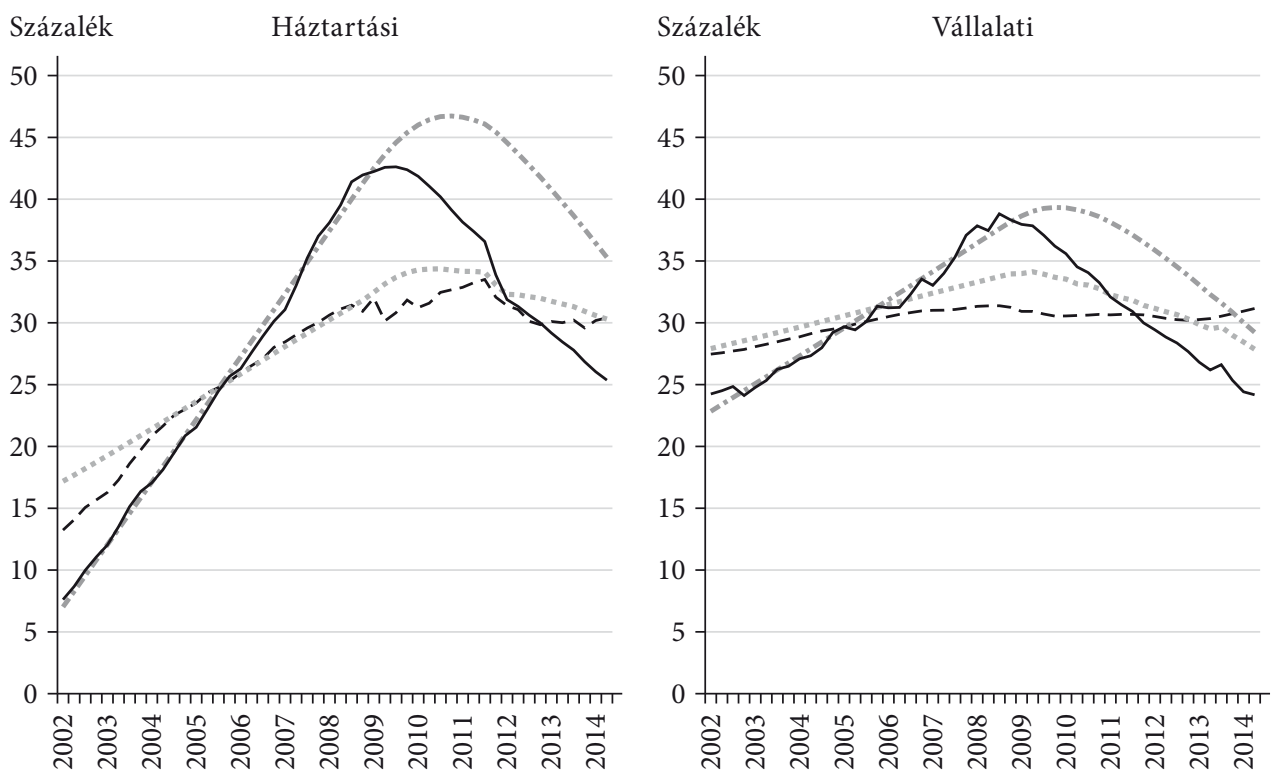

— Hitel/GDP _ - - - Többváltozós HP-trendek átlaga

$n=$ HP-trend

CF-trend

Forrás: MNB.

A válság kitörésekor a háztartási szegmensben az egyváltozós HP-szürő szerint mindössze 1 százalékpontos volt a hitelrés mértéke, míg a másik két szürő alapján körülbelül 10-10 százalékpontos. A vállalati szegmensben az egyváltozós HP-szűrő 1 százalékpont körüli hitelrést becsült, miközben a másik két szürő 5 , illetve 7 százalékpontot.

A többváltozós HP-szűrő trendje a válság kitörését követően mindkét szegmensben megtorpan, a végtörlesztéssel párhuzamosan pedig körülbelül 3 százalékpontot csökken az értéke a háztartások esetében. A trend megtorpanása és a válság kitörésekor meglevő hatalmas hitelrés miatt a hitelállomány csökkenése szinte teljes mértékben a hitelrés csökkenését vonja maga után, amely 2014-ben már negatív tartományba kerül. A CF-szürő esetében hasonló a lefutás, csak a trend megtorpanása kicsit később következik be, és a vállalati szegmensben a trend is korrigálódik. Az egyváltozós HP-szürő azonban - mivel nem jelzett pozitív hitelrést a hitelezés csúcspontján - a hitelállomány csökkenését eleinte igen nagy mértékü negatív hitelrésnek érzékeli, majd a trendérték csökkenésének hatására a negatív hitelrés kismértékben zárul. 
12. ábra

Egyváltozós szűrők és a többváltozós HP-szürő összehasonlítása - hitelrés

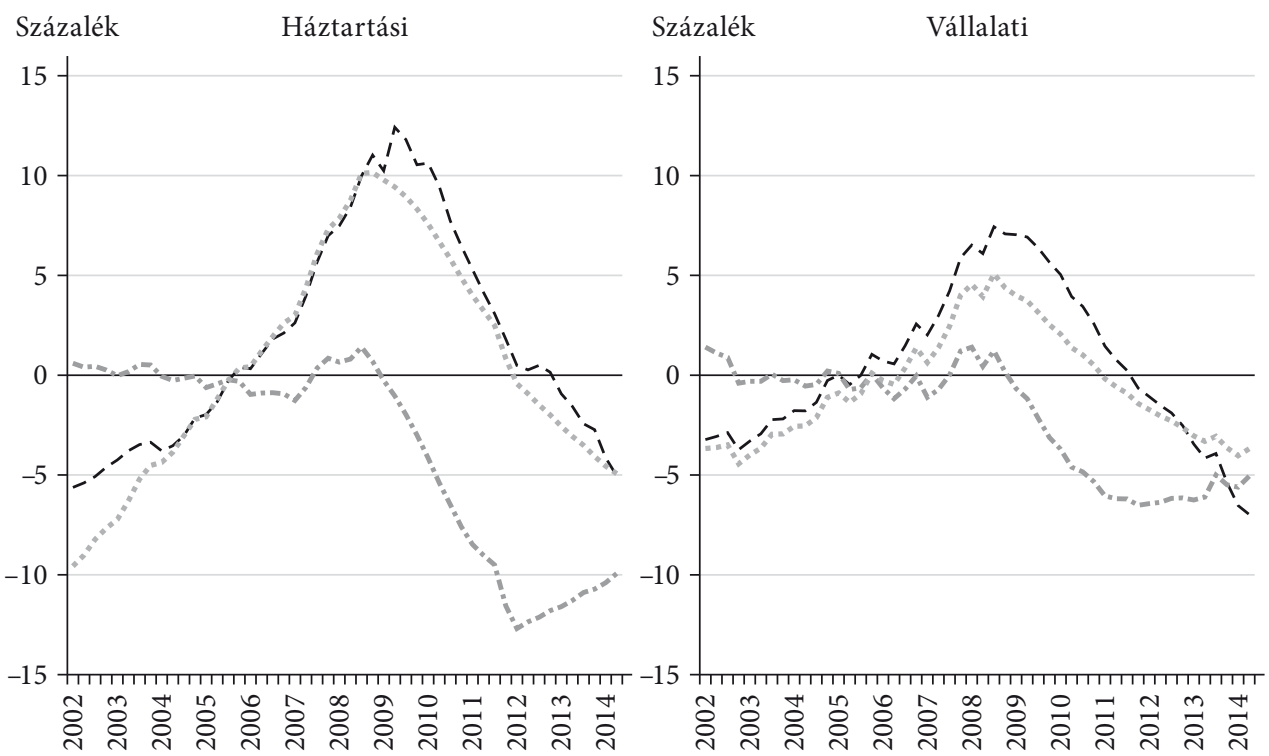

- - - Többváltozós HP-szűrő

-n-.- HP-szürő

CF-szürő

Forrás: MNB.

13. ábra

Egyváltozós szűrők és a többváltozós szűrő összehasonlítása a teljes állományra
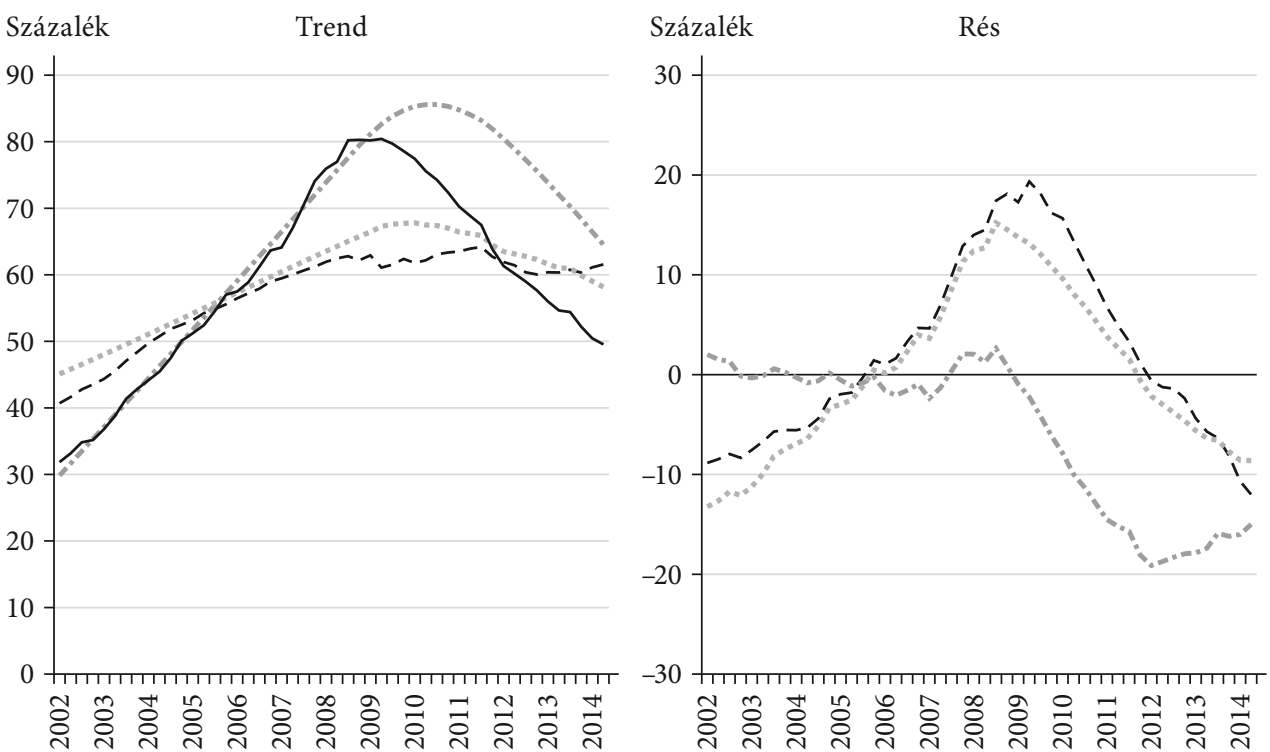

— Hitel/GDP _ - - Többváltozós HP

$=n=n$ HP

$\mathrm{CF}$

Forrás: MNB. 
Ha a háztartási és a vállalati szegmenst összegezzük (13. ábra), láthatjuk, hogy az egyváltozós HP-szürő a válság kitörésekor igen alacsony, körülbelül 2,5 százalékpontos hitelrést jelzett volna, miközben a CF-szürö 15, a többváltozós HP-szürő pedig 17 százalékpontos hitelrést mutatott volna.

A három szürőt érdemes robusztusság szempontjából is összehasonlítani, ezért mindhárom szürő esetében összevetettük a leghosszabb, vagyis a 2014 második negyedévéig tartó időhorizont eredményeit a legrövidebb és a második leghoszszabb vizsgált (vagyis 2008 negyedik negyedévéig, illetve 2013 negyedik negyedévéig tartó) időhorizont eredményeivel. Mindkét összehasonlításnál megnéztük, hogy a leghosszabb időhorizonton kapott eredményekhez képest abszolút értékben átlagosan mennyivel térnek el az egyes időszakokra becsült trendek, illetve mekkora a legnagyobb eltérés (1. táblázat).

\section{1. táblázat}

Egyváltozós szűrők és a többváltozós szűrő összehasonlítása - robusztusság (százalékpont)

\begin{tabular}{llccc}
\hline & & $\begin{array}{c}\text { Egyváltozós } \\
\text { HP-szürő }\end{array}$ & CF-szürő & $\begin{array}{c}\text { Többváltozós } \\
\text { HP-szürő }\end{array}$ \\
\hline $\begin{array}{l}\text { Átlagos abszolút eltérés 2008 } \\
\text { negyedik negyedévéig }\end{array}$ & $\begin{array}{l}\text { háztartási } \\
\text { vállalati }\end{array}$ & $\begin{array}{l}3,65 \\
2,41\end{array}$ & 1,98 & 0,39 \\
\hline $\begin{array}{l}\text { Maximális abszolút eltérés 2008 } \\
\text { negyedik negyedévéig }\end{array}$ & háztartási & 8,42 & 4,82 & 0,24 \\
\hline Átlagos abszolút eltérés 2013 & háztartási & 0,61 & 0,73 & 0,85 \\
negyedik negyedévéig & vállalati & 0,32 & 0,21 & 0,78 \\
\hline Maximális abszolút eltérés 2013 & háztartási & 2,25 & 0,72 & 0,29 \\
negyedik negyedévéig & vállalati & 1,18 & 0,57 & 0,09 \\
\hline
\end{tabular}

Forrás: MNB.

A kapott eredményeket úgy is értelmezhetjük, hogy milyen mértékben változtatná meg az egyes időszakok trendjére kapott korábbi értékeket a hosszabb időszakon való futtatás. Az eredmények alapján látszik, hogy összességében a többváltozós HP-szürőt tekinthetjük időben a legstabilabbnak: a 2008 negyedik negyedévéig való futtatás eredményeit az öt és fél évvel hosszabb időhorizonton való futtatás átlagosan csak 0,4 százalékponttal módosította a háztartási és 0,2 százalékponttal a vállalati szegmens esetében - szemben a Christiano-Fitzgerald-szűrő körülbelül 2 százalékpontos és az egyváltozós HP-szűrő 2,5-3,5 százalékpontos értékeivel. A maximális abszolút eltérést figyelembe véve a különbség még inkább szembetünő. A 2013 negyedik negyedévéig való futtatás eredményei esetében a rövidebb időbeli távolság miatt a korrekciók mértéke kisebb, és ismét a többváltozós HP-szürő értékei módosulnak a legkevésbé (leszámítva a háztartási szegmens átlagos abszolút eltérését, ahol viszont minimális a különbség a CF-szürőhöz képest). 


\section{Összegzés}

Tanulmányunk során a piaci szektor GDP-arányos hitelállományának idősorát bontottuk fel trendre és ciklikus komponensre (hitelrésre). A dekomponáláshoz több szürőeljárás is rendelkezésre áll, amelyből hármat vizsgáltunk meg részletesebben: az egyváltozós Hodrick-Prescott-szürőt, a Christiano-Fitzgerald-szürőt és a többváltozós Hodrick-Prescott-szürőt. A dekomponálást külön végeztük a háztartási és a vállalati idősor esetében, majd a kapott értékeket összegeztük.

Az egyváltozós szűrők előnye, hogy adatigényük kicsi, hiszen csak a vizsgált idősor értékeit használják fel, kevés paramétert kell kívülről megadni, illetve könnyen és gyorsan előállíthatók. A módszer alkalmazásakor azonban jelentős lehet a végponti bizonytalanság, emiatt az újabb adatok beérkezésével a korábbi időszakokra becsült értékek is változnak. Ennek nagysága az egyváltozós HP-szürő esetében olyan mértékủ volt, hogy az a módszertan használatát megbízhatatlanná tette, míg a Christiano-Fitzgerald-szürő esetében ez a hatás lényegesen kisebbnek mutatkozott.

A többváltozós Hodrick-Prescott-szürő lehetővé teszi egyéb információk beépítését a szürésbe, aminek köszönhetően pontosabb képet kaphatunk a folyamatok alakulásáról. A szürő beállítása ugyanakkor több szakértői döntést igényel, ami a kapott trend értékére is hatással van. A többváltozós szüröt bizonyos keretek között különböző lehetséges módokon futtattuk, és végül az eredmények átlagát használtuk a trend értékeként az összehasonlítás során. Azt tapasztaltuk, hogy a többváltozós Hodrick-Prescott-szürő esetében a legkisebb a végponti bizonytalanság, illetve a kapott eredmények nagyjából egybevágnak a hitelrés alakulásáról kialakított szakértői képpel. Ezért összességében a vizsgált módszerek közül a többváltozós szürő a legalkalmasabb szabályozói célokra (anticiklikus tőkepuffer meghatározására).

A többváltozós Hodrick-Prescott-szürő alapján a 2000-es évek elején, a pénzügyi mélyülés során a kezdetben negatív hitelrés zárult, de a további hitelállománynövekedés jelentős mértékben emelte a pozitív értékü hitelrést mind a háztartási, mind a vállalati szektorban. A háztartási szektorban a válság kitörésekor a hitelrés értéke a szürő alapján 10, míg a vállalati szektorban 7 százalékpont volt. A válságot követő alkalmazkodás során a hitelrés ismét zárult, sőt a nagymértékű csökkenés miatt megint negatív lett az értéke.

\section{Hivatkozások}

Alessi, L.-Detken, C. [2011]: Quasi real time early warning indicators for costly asset price boom/bust cycles: A role for global liquidity. European Journal of Political Economy, Vol. 27. No. 3. 520-533. o. http://dx.doi.org/10.1016/j.ejpoleco.2011.01.003.

Backé, P.-Égert, B.-Zumer, T. [2006]: Credit Growth in Central and Eastern Europe: Emerging from Financial Repression to New (Over)Shooting Stars? ECB Working Paper Series, No. 687. 
BCBS [2010]: Guidance for national authorities operating the countercyclical capital buffer. Basel Committee on Banking Supervision, Bank for International Settlements, http://www. bis.org/publ/bcbs187.pdf.

Buncic, D.-Melecky, M. [2014]: Equilibrium credit: The reference point for macroprudential supervisors. Journal of Banking and Finance, Vol. 41. 135-154. o. http://dx.doi.org/ 10.1016/j.jbankfin.2014.01.005.

Christiano, L. J.-Fitzgerald, T. J. [2003]: The Band Pass Filter. International Economic Review, Vol. 44. No. 2. 435-465. o. http://dx.doi.org/10.1111/1468-2354.t01-1-00076.

Compton, R. A.-DA Costa e Silva, J. R. [2005]: Finance and Business Cycle: a Kalman Filter Approach with Markow Switching. The Banco Central do Brasil Working Papers, No. 97.

Detren, C.-Weeken, O.-Alessi, L.-Bonfim, D.-Boucinha, M. M.-Castro, Ch.-Frontczak, S.-Giordana, G.-Giese, J.-Jahn, N.-Kakes, J.-Klaus, B.-Lang, J. H.-Puzanova, N.-WeLz, P. [2014]: Operationalising the countercyclical capital buffer: indicator selection, threshold, identification and calibration. ESRB Occasional Paper Series, No. 5.

Drehmann, M.-Borio, C.-Gambacorla,-Jimérez, G.-Trucharte, C. [2010]: Countercyclical capital buffers: exploring options. BIS Working Paper, No. 317. http://dx.doi. org/10.2139/ ssrn.1648946.

Edge, R. M.-Meisenzhal, R. R. [2011]: The Unreliability of Credit-to-GDP Ratio Gaps in Real Time: Implications for Countercyclical Capital Buffers. International Journal of Central Banking, Vol. 7. No. 4. 261-298. o.

Endrész Marianna [2011]: Business Fixed Investment and Credit Market Frictions. A VECM Approach for Hungary. MNB Working Papers, 2011/1.

ERKT [2014]: Az Európai Rendszerkockázati Testület ajánlása (2014. június 18.) az anticiklikus tőkepufferráták meghatározására vonatkozó útmutatásról (ERKT/2014/1). Az Európai Unió Hivatalos Lapja, 2014. szeptember 2. 2014/C 293/01. http://eur-lex.europa.eu/legalcontent/HU/TXT/?uri=CELEX:32014Y0902\%2801\%29.

Hirose, Y.-Kamada, K. [2003]: A New Technique for Simultaneous Estimation of Potential Output and the Phillips Curve. Monetary and Economic Studies, Bank of Japan, Vol. 21. No. 2. 93-112. o.

Hodrick, Y.-Prescott, E. C. [1997]: Postwar U.S. Business Cycles: An Empirical Investigation. Journal of Money, Credit, and Banking, Vol. 29. No. 1. 1-16. o. http://dx.doi. org/10.2307/ 2953682.

Hosszú Zsuzsanna-KöRmEndi GyöngYi-MéRő BENCE [2015]: Egy- és többváltozós szűrők a hitelrés alakulásának meghatározására. MNB-tanulmányok, 118.

Kiss Gergely-Nagy Márton-Vonnák Balázs [2006]: Credit Growth in Central and Eastern Europe: Convergence or Boom? MNB Working Papers, 2006/10.

Laxton, D.-Tetlow, R. [1992]: A simple multivariate filter for the measurement of potential output. Bank of Canada Technical Report, No. 59.

Mody, A.-SARno, L.-TAYLOR, M. [2007]: A cross-country financial accelerator: Evidence from North America and Europe. Journal of International Money and Finance, Vol. 26. No. 1. 149-165. o. http://dx.doi.org/10.1016/j.jimonfin.2006.10.009. 


\section{Függelék}

A tanulmányban használt és a szakirodalomban fellelhetö többváltozós HP-szürők közötti különbségek

Ahogy azt a Többváltozós Hodrick-Prescott-szürő címü fejezetben említettük, többfajta többváltozós HP-becslési megoldás is létezik, amelyek közül a LaxtonTetlow- és a Hirose-Kamada-féle eljárásokat emeltük ki. Laxton és Tetlow két regressziós összefüggéssel egészítette ki az egyváltozós HP-szűrőt, és a regressziós egyenletek hibatagjait szerepeltette a megoldandó feladat célfüggvényében. Hirose és Kamada ezzel szemben közvetlenül a célfüggvényben cserélte ki az egyváltozós HP-szűrő illeszkedést előíró tagját egy regressziós egyenlettel. Utóbbi eljárás ezért csak egy közgazdasági összefüggést tud figyelembe venni. Az általunk használt modell felírásában megegyezik a Laxton-Tetlow-féle megoldással, azonban két fontos tulajdonságában eltér attól. Ezek elsősorban technikai tulajdonságok, amelyek cikkünk megértésében nem játszanak fontos szerepet, ugyanakkor a modell mélyebb megismerésében segítenek.

Mindkét korábbi cikkben a modellek becslése iterációs lépéseken keresztül történt. Ezzel szemben mi analitikus úton oldottuk meg az optimalizálási feladatot, így a programfutás szempontjából gyorsabban jutottunk el az eredményekhez. A két regressziós összefüggést átrendezve és behelyettesítve a célfüggvénybe, egy lépésben megkaphatók az optimális paraméter- és trendértékek.

A másik jelentős különbség a korábbi tanulmányokhoz képest a regressziós egyenletek meghatározásában van. A két hivatkozott irodalomban a potenciális GDP-t becsülték meg, amelyhez egy vagy két konkrét közgazdasági összefüggést illesztettek hozzá: a Phillips-görbét és az Okun-törvényt. Ezzel szemben mi olyan változókat kerestünk, amelyek együtt mozoghatnak a hitelezés trendjével vagy ciklusával, ezért segíthetnek az identifikációban. Mivel nem tudtuk pontosan, mely változók müködnek megfelelöen, ezért több specifikációt is kipróbáltunk, és csak bizonyos feltételekkel fogadtuk el a becslési eredményeket, szemben a korábbi cikkekkel. Mivel nem ok-okozati alapon fogalmaztuk meg az egyenleteket, csak együttmozgást kerestünk, ezért a regressziós egyenletek között elöfordulhat hamis regresszió. Emiatt nem használhattuk a változók kiválasztásánál a $p$-értékeket, ugyanakkor a hamis regresszió a mi esetünkben nem ad teljesen használhatatlan eredményeket. Mivel ebben a becslésben a célváltozó látens (ebből kifolyólag becslendő), ezért az identifikálásában segíthet egy olyan összefüggés, amely a látens változó és a megfigyelt magyarázóváltozó közötti összefüggést ragadja meg. 


\section{Érzékenységvizsgálatok az alkalmazott feltevésekre}

F1. ábra

A háztartási és a vállalati hitel/GDP egyoldali Christiano-Fitzgerald-trendje különböző ciklushosszokkal, a trendszüréskor determinisztikus trendet feltételezve
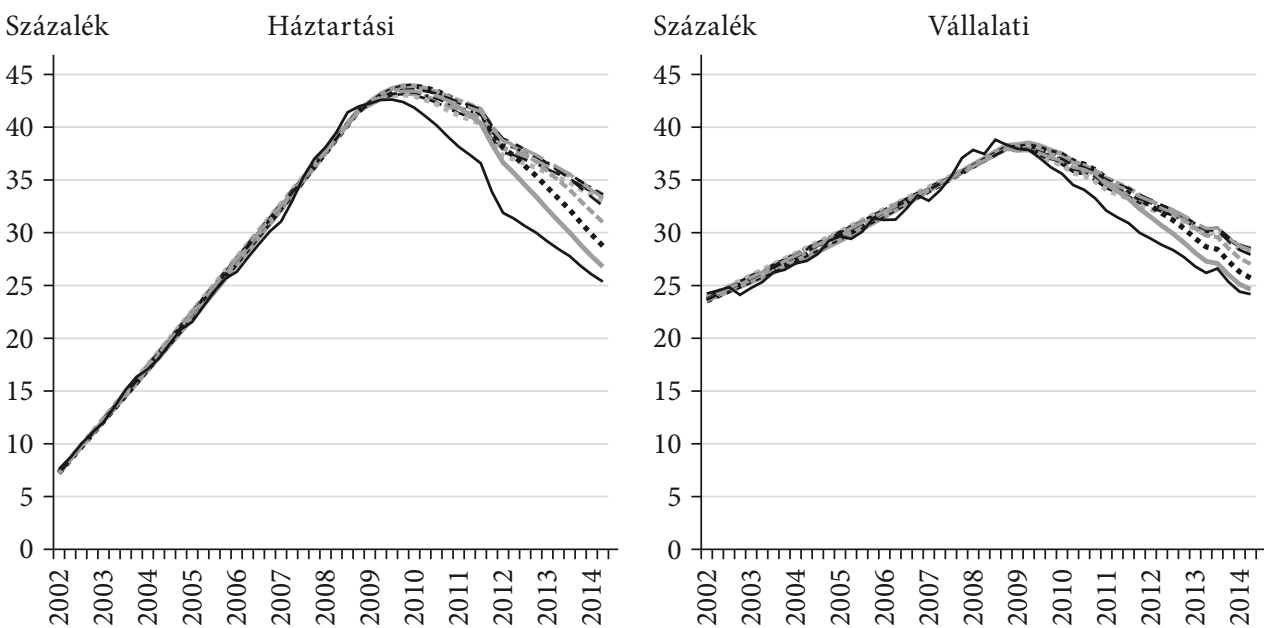

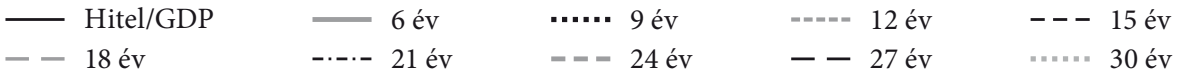

Forrás: MNB.

F2. ábra

A háztartási és a vállalati hitel/GDP kétoldali többváltozós Hodrick-Prescott-trendje a változókkal kapcsolatos különböző szignifikanciakritériumok mellett
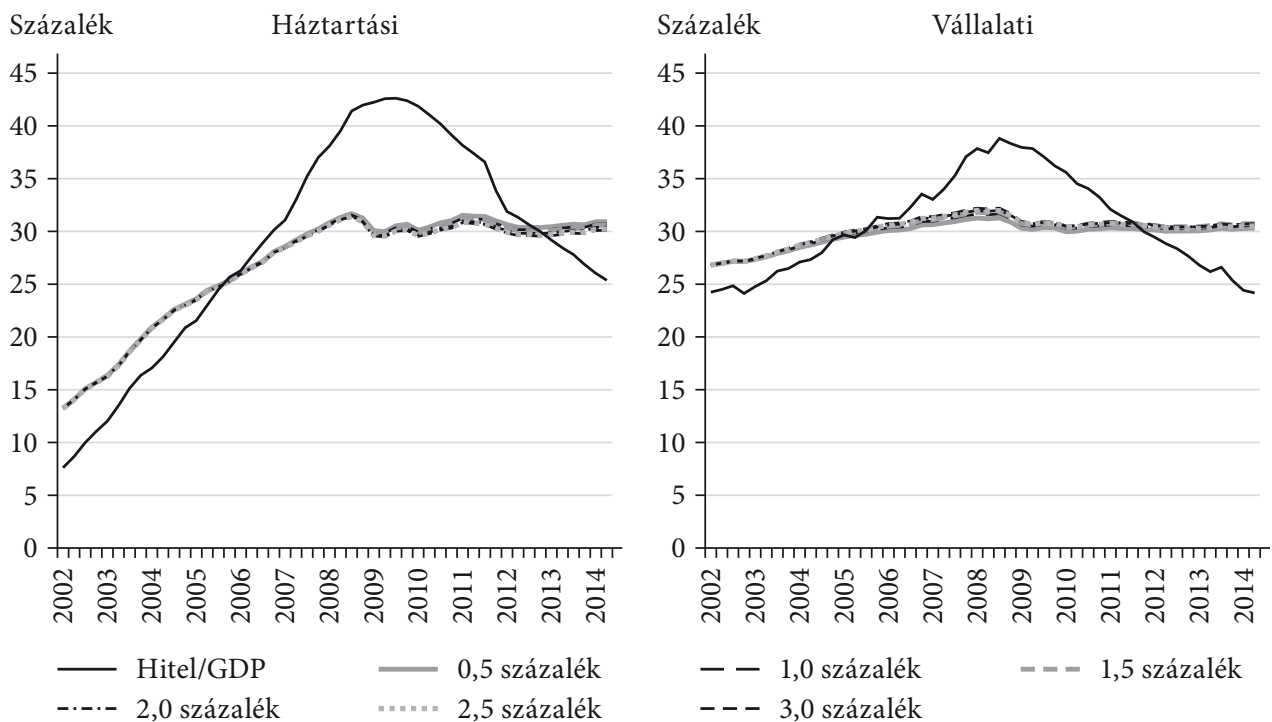

Forrás: MNB. 
F3. ábra

A háztartási és a vállalati hitel/GDP kétoldali többváltozós Hodrick-Prescott-trendje különböző indulóértékek mellett

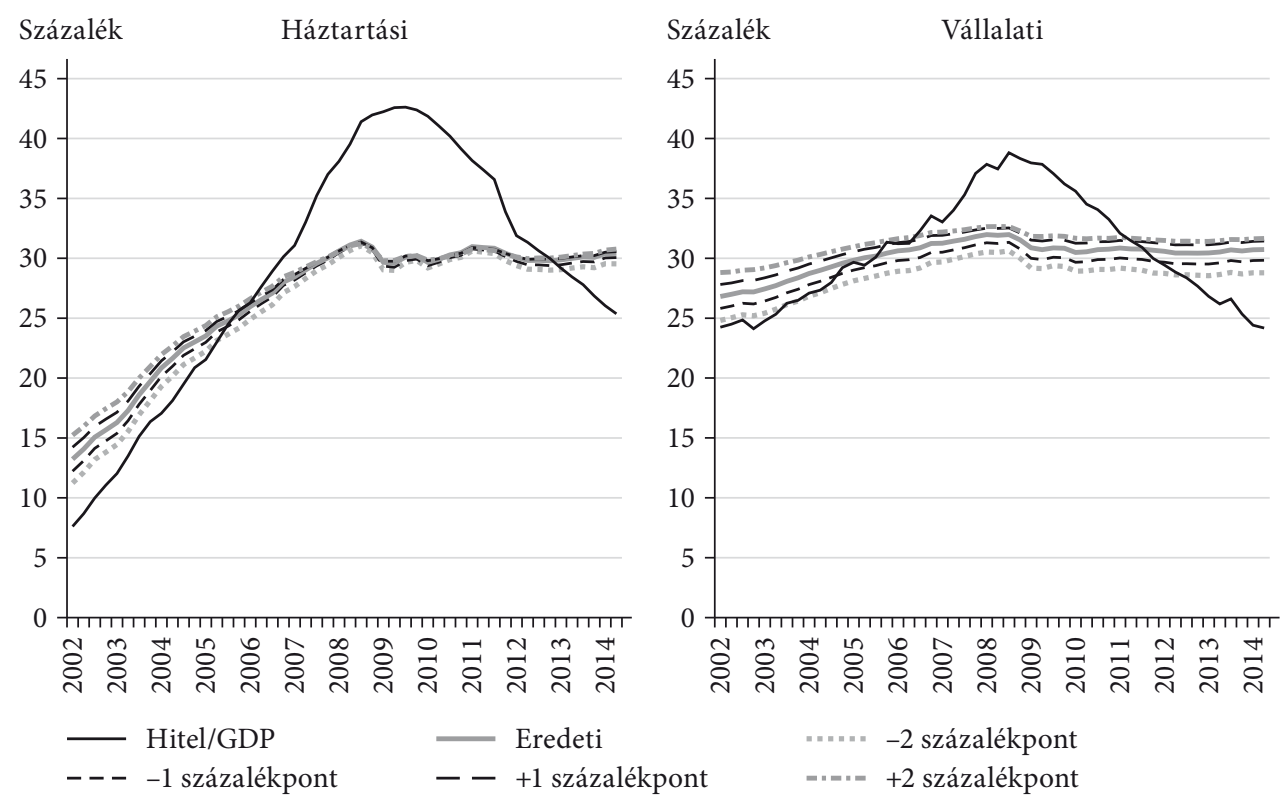

Forrás: MNB. 